PONTIFÍCIA UNIVERSIDADE CATÓLICA DO RIO DE JANEIRO

\title{
Comportamento do Consumidor e a atratividade das capas de discos de música
}

Renato Penna Magoulas Bacha

Trabalho de Conclusão de Curso

CENTRO dE CIÊNCIAS SOCIAIS - CCS

DePARTAMENTO de AdMINISTRAÇÃo

Graduação em Administração de Empresas 


\section{Comportamento do Consumidor e a atratividade das capas de discos de música}

Trabalho de Conclusão de Curso, apresentado ao programa de graduação em Administração da PUC-Rio como requisito parcial para a obtenção do titulo de graduação em Administração.

Orientador: Marcus Wilcox Hemais

Rio de Janeiro, Junho de 2016. 
"I began to realize how important it was to be an enthusiast in life... if you are interested in something, no matter what it is, go at it all full speed ahead. Embrace it with both arms, hug it, love it and above all become passionate about it." (Roald Dahl) "Always look on the bright side of life" (Eric Idle) "Transforme as pedras que você tropeça em pedras da sua calçada” (Sócrates) 


\section{Agradecimentos}

Desde 2012, ano que entrei na Administração, minha vida mudou, foram quatro anos de muito aprendizado, amadurecimento, certezas e incertezas. Foram anos muito importantes e, é com muito orgulho que me torno um futuro ex-aluno da PUC e do IAG, um filho da PUC!

Nesse momento, gostaria de agradecer pessoas importantes na minha vida. Primeiramente, meu pai por ter me dado a oportunidade de estudar, apoiandome em minhas decisões, certas ou erradas, incentivando-me a melhorar sempre, e também por ser meu herói. Gostaria de agradecer à minha mãe por, acreditar no meu potencial, em todas as fases da minha vida, e por ser minha heroína. Aos meus amigos, que conheci ao longo da jornada PUC, aos que já não estão mais ao meu lado e aos que ficaram, muito obrigado por tudo. Aos meus amigos antigos, que acreditam e que sempre acreditaram em mim, e que me querem sempre bem daqui à eternidade.

Gostaria de agradecer a todos os professores que cruzaram meu caminho, seja na Administração, ou na Engenharia, pois cada um foi importante na minha formação de diferentes maneiras. Em especial, meu orientador, Marcus Hemais, por ter sido um professor muito importante, por ser divertido, por acreditar nos seus alunos e aceitar alunos com "sangue nos olhos", incentivando-nos a não desistir nunca. Um beijo e um agradecimento especial para Alessandra Baiocchi, que me despertou a paixão pelo Marketing, e por ser um exemplo de pessoa que inspira todos ao seu redor. Obrigado, aos dois, por terem acreditado em mim e pela paciência e dedicação nesses quatro anos!

Um agradecimento especial ainda a todos os entrevistados, que fizeram esse trabalho ganhar forma, e que disponibilizaram seu tempo precioso para esta pesquisa, compartilhando esse tema tão maravilhoso que é a música.

Obrigado a todos! 


\section{Resumo}

De Penna Magoulas Bacha, Renato. Comportamento do Consumidor e a atratividade das capas de discos de música. Rio de Janeiro, 2016. 61 p. Trabalho de Conclusão de Curso - Departamento de Administração. Pontifícia Universidade Católica do Rio de Janeiro.

O presente estudo tem como objetivo identificar e analisar os fatores que levam consumidores a comprarem discos por impulso, somente avaliando suas capas. Para entender essa questão, foram realizadas entrevistas em profundidade, com roteiro semiestruturado, com 15 consumidores. Foram analisados temas como atitude, heurística, percepção e semiótica, e como esses são percebidos e avaliados para a compra por impulso de um disco de música. Com os resultados da pesquisa, foi possível verificar qual é o tipo de capa que mais impacta o consumidor e qual seria a linha para as bandas seguirem se quiserem focar nas capas.

Palavras-chave: capas de discos de música, estímulos sensoriais, percepção, atitude, consumidores. 


\section{Abstract}

De Penna Magoulas Bacha, Renato. Consumer Behavior and the Attractiveness of music album covers. Rio de Janeiro, 2016. 61 p. Trabalho de Conclusão de Curso - Departamento de Administração. Pontifícia Universidade Católica do Rio de Janeiro.

This study aims to identify and analyze the factor that lead consumers to buy music discs, only evaluating their covers. To understand this issue was held in-depth interviews with semi-structured, with 15 consumers. In order to understand this matter, subjects were analyzed as attitude, heuristics, perception and semiotics, and how these senses are perceived and evaluated for the impulse purchase of a music disc. With the survey results, was found what kind of cover most impacts the consumer and what would be the line bands needs to follow if they want to focus on their covers

Key words: Covers of music albums, sensory stimuli, perception, attitude, consumers. 


\section{Sumário}

1 O tema e o problema de estudo 1

1.1. Introdução ao tema e ao problema do estudo 1

1.2. Objetivo Final 2

1.3. Objetivos intermediários 2

1.4. Delimitação do estudo 2

1.5. Relevância do estudo 3

2 Evolução das mídias musicais na indústria fonográfica 4

3 Referencial Teórico $\quad \underline{76}$

3.1. Percepção $\underline{76}$

3.2. Atitude $\underline{109}$

3.3. Heurística $\underline{1210}$

4 Métodos e procedimentos de coleta e de análise de dados do estudo 1412

4.1. Tipo de pesquisa $\quad \underline{1412}$

4.2. Seleção de Sujeitos $\quad \underline{15} 13$

4.3. Coleta de dados $\quad \underline{16} 14$

4.4. Tratamento de dados $\underline{1715}$

4.5. Limitações do método 1715

5 Análise dos resultados $\quad \underline{19} 17$

5.1. Experiências pessoais com discos e suas capas 1917

5.2. Análise sobre capas de discos $\underline{3129}$

6. Conclusão $\underline{4240}$

6.1. Implicações Gerenciais $\quad 41$

6.2. Sugestões e recomendações para futuros estudos 42

$\begin{array}{ll}\text { Anexos } & 4543\end{array}$

7 Referências Bibliográficas $\quad \underline{5351}$ 


\section{0 tema e o problema de estudo}

\subsection{Introdução ao tema e ao problema do estudo}

A imagem é um dos meios de expressão que o ser humano vem utilizando desde os primórdios para se relacionar, mostrar conhecimento, revelando o diaa-dia, para gerações futuras. Desde as pinturas rupestres, ações e emoções da era pré-histórica têm sido reveladas. Ao longo do tempo, as imagens saíram das paredes das cavernas e foram parar em vasos gregos, quadros de artistas, desenhos em jornais e revistas, e diversos outros elementos cotidianos da sociedade. Um desses elementos são as capas de álbuns de música.

Para chamar atenção do público, desde meados do século $X X$, quando se começaram a utilizar vinis para comprimir músicas, e assim difundi-las ao redor do planeta, cantores e bandas se utilizaram de várias formas e estilos de imagens e desenhos em suas capas para atrair novos compradores. Apesar das capas serem apenas coadjuvantes em relação à música, algumas chamam atenção e se destacam mais do que o próprio conteúdo.

Com o advento da Internet, é difícil não associar a banda/cantor à capa em si, pela facilidade de identificar o autor daquela imagem, e, consequentemente, se vai gostar ou não do conteúdo veiculado. Porém, até a década de 1990, o hábito de ir até a loja que vendia discos e olhar para uma capa e comprar pelo impulso, ou seja, comprar porque gostou da capa, era comum, mesmo não conhecendo o que havia dentro do famoso Long Play (LP) ou do mais recente Compact Disc (CD).

Regis Tadeu, jornalista do site Yahoo, em sua coluna semanal, afirmou :

Ainda hoje não consigo dimensionar direito o impacto que tive em 1981, quando comprei a edição importada do Killers, da banda Iron Maiden, no Museu do Disco, em São Paulo. E comprei só por causa da capa sensacional, pois não tinha a menor ideia de como era o som da banda, lembrando que não existia internet na época. (TADEU,2015) 
A partir desse contexto, o intuito desse trabalho é refletir sobre a seguinte questão: quais os motivos que levam consumidores a comprarem discos por impulso, somente avaliando suas capas?

\subsection{Objetivo Final}

O objetivo final do presente estudo é identificar e analisar os fatores que levam consumidores a comprarem discos por impulso, somente avaliando suas capas.

\subsection{Objetivos intermediários}

De forma a alcançar o objetivo final do estudo, é necessário chegar aos seguintes objetivos intermediários, que são estudar termos relacionados ao Comportamento do Consumidor, tais como percepção, atitude e heurística; e identificar os atributos de uma capa de disco que chamam a atenção dos consumidores.

\subsection{Delimitação do estudo}

Embora o conhecimento do artista ou banda e o seu estilo musical sejam grandes influências para alguém comprar um disco, somente serão avaliados aspectos da capa dos discos no presente estudo.

As capas a serem analisadas são de discos de diversos estilos musicais, tais como música eletrônica, folk, indie rock, blues, heavy metal, pop, rock e rap. Também, o estudo não será restrito a analisar somente as capas de discos de um artista ou banda; o objetivo é misturar diversos artistas, conhecidos ou não do público, cujas músicas sigam os gêneros apontados.

O público que será alvo da investigação é formado por consumidores da faixa etária de 25 a 50 anos, que viveram na época pré-internet no Brasil e que frequentavam as lojas de discos locais para consumir música. 


\subsection{Relevância do estudo}

Este estudo é relevante para dois grandes públicos: o meio empresarial/fonográfico e o meio acadêmico.

Entre os trabalhos acadêmicos, tanto nacionais quanto internacionais, 0 assunto em questão foi pouco discutido, especialmente dentro da literatura de marketing. Logo, trazer mais conhecimento sobre esse tema é válido e ajuda a entender mais sobre a relação entre consumidores e música.

Em relação ao meio fonográfico, esse tema é relevante para entender quais são os motivos pelos quais os consumidores são atraídos pela capa na hora de comprar discos de um artista desconhecido. Portanto, mais um motivo para contratar designers, artistas plásticos, fotógrafos e desenhistas para as capas, atendendo aos apelos do artista/gravadora, na hora de criar uma "capa perfeita" aos olhos do público em geral. 


\section{Evolução das mídias musicais na indústria fonográfica}

Em uma reportagem intitulada "Os operários da música livre", da revista Galileu, Ronaldo Evangelista retratou e investigou a história da música compactada. Segundo Evangelista (2013), essa história começou em 1877, quando Thomas Edison, inventor norte-americano, patenteou o fonógrafo, que era um aparelho que, através de cilindros, gravava e reproduzia sons. Depois de algum tempo, Alexander Graham Bell, que desenvolvia uma ideia parecida, criou o grafófono, cuja única diferença consistia na utilização de um cilindro de cera.

Emile Berliner, dez anos depois, em 1887, patenteou o gramofone, que tocava sons gravados, em chapas chatas e redondas, inicialmente com diferentes matérias primas e tamanhos, e, com isso, nasceu o "disco". Na virada do século $X X$, criou-se um formato redondo, de "disco", girando a 78 rotações por minuto e com 10 polegadas, contabilizando o que futuramente seria chamado de "single", com uma música de cada lado, na época, mais ou menos com 3 minutos (EVANGELISTA, 2013).

Em 1948, foi inventado pela gravadora Columbia o Long Play, ou "LP" como foi popularizado, feito de vinilite e girando a 33 rotações por minuto, formato menor daquele criado no início do século. Ele também é chamado de vinil (ou vinyl, em inglês), devido ao material com que é produzido. Ao longo dos anos, surgiram vários tamanhos e evoluções dos mesmos, sempre tentando melhorar a qualidade sonora e adequar mais faixas dentro dos discos (EVANGELISTA, 2013).

Na década de 1960, a Philips inventou a fita cassete, uma nova forma de compactação, e, em 1982, os primeiros Compact Disc, ou "CD" foram lançados, e eram os primeiros com leitura laser, e comportando em um só lado cerca de 80 minutos. Isso representou a "morte" dos $L P$ 's, que tinham que se dividir em dois lados se quisessem compor 80 minutos, e o cassete também perdeu espaço porque o $C D$ era mais fácil de transportar para qualquer lugar (EVANGELISTA, 2013).

Porém, em 1995, chegou ao mercado o "vilão" e o grande pivô de toda a revolução no mercado fonográfico atual, o "MP3", que é um formato de compressão de música digital, e que foi patenteado por um instituto alemão de 
áudio chamado Fraunhofer (CRUZ, 2015). Até hoje, com a popularização da Internet, essa é a forma pela qual as pessoas compartilham e baixam música, muitas vezes de graça. Os artistas podem disponibilizar, através de programas e plataformas online, suas músicas, por um preço acessível.

A indústria fonográfica é formada por um conjunto de empresas especializadas em gravação e distribuição sonora, nos vários formatos de mídias existentes, tanto em CD'S, MP3 e vinis.

Segundo relatório da Federação Internacional da Indústria Fonográfica IFPI (2016), houve uma receita de vendas de músicas em todas as plataformas de U\$ 15 bilhões, com um crescimento de 3,2\% em relação a 2015 , sendo o primeiro aumento significativo de vendas desde 1998. Os dados de vendas foram divididos entre as vendas físicas (CD's e $L P$ 's), com uma queda de 7,0\% em 2015, em relação a 2014, que representou 39\% das vendas. As receitas da área digital representaram $45 \%$ das vendas mundiais de música, por influência, principalmente, do bom desempenho do segmento de subscrição para acesso à música por streaming, que segue sendo o modelo com mais potencial de crescimento nos próximos anos dentro desse mercado. O streaming é uma forma de distribuir informações de áudio e vídeo pela internet, através de pacotes, pagos ou não. Exemplos de sites de streaming são iTunes, Deezer e Spotify.

Porém, uma reportagem do site Administradores (2015), afirmou que "de acordo com um relatório divulgado pela RIAA (Recording Industry Association of America), os serviços de streaming online de música geraram, nos EUA, US\$ 163 milhões, enquanto que a venda de vinis rendeu US\$222 milhões," cerca de US\$ 59 milhões a mais que as músicas online. Isso pode significar que o vinil voltou a ter valor comercial, talvez por causa dos admiradores antigos e novos, que se constituem como um público consumidor mais específico desse tipo de produto, que já representa quase um terço das vendas de música em formato físico.

Ainda segundo os dados do IFPI (2016), o restante da porcentagem foi dividido entre pagamentos de direitos autorais, cerca de $14 \%$, e o que eles denominaram de "sincronização", que corresponde a $2 \%$, que designam o uso das músicas em anúncios comerciais, filmes, games e programas de televisão. $A$ América Latina foi, pelo quinto ano consecutivo, a região mundial com maior aumento de compra de música em todos os setores, cerca de $11,8 \%$. A música digital cresceu $44,5 \%$, quatro vezes mais que a média global, e o serviço de streaming teve um aumento de $80,4 \%$ em relação a anos anteriores. De acordo 
com uma reportagem de Ferraz (2016), esse formato cresceu 192\% em relação a 2014, estando no topo do mercado brasileiro. 


\title{
3 Referencial Teórico
}

O capítulo a seguir é dedicado a discutir os temas de relevância teórica para o presente estudo. Assim, são apresentados debates sobre a percepção do consumidor, atitude e heurística.

\subsection{Percepção}

Percepção é a função cerebral que atribui significado a estímulos sensoriais, partindo de um histórico de vivências passadas. Solomon (2011, p.83), define percepção como:

\begin{abstract}
Processo pelo qual as pessoas selecionam, organizam e interpretam sensações, que estão relacionadas com a reação imediata de nossos receptores sensoriais (olhos, ouvidos, nariz, boca, pele). O estudo da percepção concentra-se no que acrescentamos nessas sensações em estado bruto a fim de Ihes darem significados, que variam de acordo com suas próprias experiências, concepções e desejos.
\end{abstract}

De acordo com Schiffman e Kanuk (2000), a percepção é definida como o processo pelo qual um indivíduo seleciona, organiza e interpreta estímulos visando a um quadro significativo e coerente do mundo. Um estímulo funciona como qualquer unidade de dados para qualquer um dos sentidos.

Ainda, segundo Solomon (2011), o processo perceptivo engloba três principais etapas, conforme apontado na Figura 1, a seguir:

Figura 1: Visão Geral do processo perceptivo

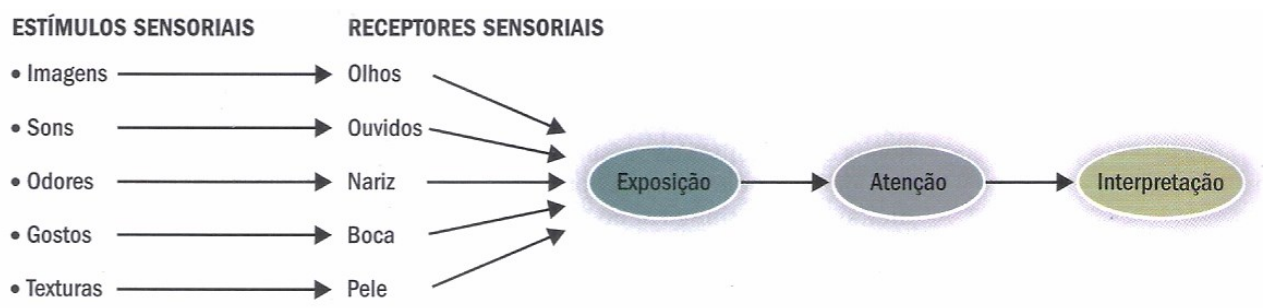

Fonte: Solomon (2011) 
Para exemplificar o processo perceptivo, Solomon (2011, p.94) afirma que "a exposição ocorre quando um estímulo penetra na gama de receptores sensoriais de uma pessoa, para Engel et al. (2000), a exposição ocorre quando o consumidor entra em contato físico com um estímulo e finalmente segundo Hawkins (2007), grande parte dos estímulos aos quais os indivíduos são expostos são "auto-selecionados", ou seja, para o autor, buscam-se exposição a certos estímulos, acreditando que essas informações Ihes ajudarão a alcançar seus objetivos e evitar outros.

A atenção, segundo Solomon (2011, p.94), refere-se ao grau em que a atividade de processamento é dedicada a um estímulo específico. Já para Engel et al. (2000), a atenção é a alocação da capacidade de processamento a um estímulo e ainda Hawkins (2007) conclui que a atenção acontece sempre dentro do contexto de uma situação, e é determinada por três fatores relacionados ao estímulo, ao indivíduo e à situação.

A interpretação é o significado que atribuímos aos estímulos sensoriais (SOLOMON, 2011). Engel (2000) reafirma a interpretação como a última etapa do processo e que os indivíduos atribuem significados diferentes aos estímulos. (ENGEL ET AL., 2000). Hawkins (2007) completa que a interpretação é considerada um processo chamado de relatividade perceptiva, por ser relativa e não absoluta.

Segundo Ribeiro e Perez-Nebra (2003, apud Mowen \& Minor, 2008), a percepção termina no estágio de compreensão; a aceitação ou não do armazenamento da imagem fazem parte da memória. No primeiro estágio, a exposição ocorre com a proximidade de um estímulo. Atenção é a disposição da capacidade de processamento do estímulo da imagem em si, e ela é influenciada por dois tipos de determinantes: pessoal e de estímulo. Determinantes pessoais são características do próprio indivíduo, como necessidade do produto, atitude, crenças, valores. Determinantes de estímulos são características e estrutura do produto, como por exemplo, tamanho e cor.

\subsection{1 - Cores}

Para Carvalho (2015), "84,7\% dos consumidores acreditam que as cores de um produto são muito mais importantes que outros fatores" e "93\% das pessoas avaliam e observam as cores e o aspecto visual de um produto na hora de comprar". Além disso, "80\% das pessoas acreditam que as cores aumentam o reconhecimento da marca", "90 segundos é a duração de uma análise sobre 
um produto" e "2 em 3 consumidores não compram o produto se não for da cor favorita deles".

Nessa mesma pesquisa de Carvalho (2015), são apontadas as diferenças entre as cores favoritas de homens e mulheres, expostas nos Quadros 1 e 2:

Quadro 1 - Cores Favoritas dos Homens

\begin{tabular}{|c|c|}
\hline Cores Favoritas Homens & $\%$ \\
\hline Azul & $57 \%$ \\
\hline Verde & $14 \%$ \\
\hline Preto & $9 \%$ \\
\hline Vermelho & $7 \%$ \\
\hline Laranja & $5 \%$ \\
\hline Cinza & $3 \%$ \\
\hline Marrom & $2 \%$ \\
\hline Branco & $2 \%$ \\
\hline Amarelo & $1 \%$ \\
\hline
\end{tabular}

Fonte: Carvalho (2015)
Quadro 2 - Cores Favoritas das Mulheres

\begin{tabular}{|c|c|}
\hline Cores Favoritas Mulheres & $\%$ \\
\hline Azul & $36 \%$ \\
\hline Roxo & $23 \%$ \\
\hline Verde & $14 \%$ \\
\hline Vermelho & $9 \%$ \\
\hline Preto & $6 \%$ \\
\hline Laranja & $5 \%$ \\
\hline Marrom & $3 \%$ \\
\hline Amarelo & $3 \%$ \\
\hline Cinza & $1 \%$ \\
\hline
\end{tabular}

Fonte: Carvalho (2015)

Já segundo Hoyer e Maclnnis (2011,), a cor é um fator extremamente importante na percepção visual, e esta determina se vemos os estímulos ou não. Determinada cor pode ser descrita de acordo com três itens: matiz, saturação e brilho. O matiz se refere ao pigmento contido na cor, e as cores podem ser classificadas em duas categorias: cores quentes (vermelho, laranja e amarelo), e cores frias (verdes, azul e violeta). A saturação refere-se à riqueza de cor, levando a distinções como rosa pálido ou rosa escuro forte, e o brilho refere-se à profundidade do tom na cor. Os autores ainda dizem que as cores influenciam nossas respostas fisiológicas e o nosso humor. Cores quentes geralmente incentivam atividades e animação, e cores frias são mais tranquilizantes e relaxantes. Por sua vez, cores mais profundas e escuras com maior saturação evocam mais excitação que cores menos profundas e mais claras.

\subsection{2 - Semiótica}

Para auxiliar a compreensão dos consumidores em relação à simbologia, que é o estudo ou interpretação dos símbolos, existe um campo de estudo chamado semiótica, que examina a relação entre signos e símbolos e seu papel na atribuição de significado. Para Solomon (2011, p.109), a semiótica é importante para: 


\begin{abstract}
Compreendermos o comportamento dos consumidores, do porque estes usam produtos para expressar suas identidades sociais. Os produtos têm significados aprendidos, e confiamos nos profissionais de marketing para nos ajudar a entender quais são esses significados.
\end{abstract}

Ainda segundo Solomon (2011, p.109), "toda mensagem de marketing tem três componentes principais: um objeto, signo/símbolo e tradução". O "objeto é o produto que é foco da mensagem", ou seja, no caso da presente pesquisa, o disco comprado pelo consumidor. O "signo/símbolo é a imagem sensorial que representa os significados que o objeto mostra", ou seja, a capa do álbum e seus atributos. A "tradução é o significado derivado do produto", ou seja, se a capa do álbum vai traduzir no consumidor alegria, tristeza ou outro sentimento qualquer.

Já para Schiffman e Kanuk (2001, p.199), o estudo da semiótica é a: "análise dos significados implícitos dos sinais e símbolos". Os autores também dizem que:

\footnotetext{
Pesquisadores também usam a semiótica para descobrir os significados de vários comportamentos e rituais de consumo. É importante entender os significados que os símbolos nãoverbais podem ter para o público alvo a fim de se certificar de que os símbolos estimulam, em vez de inibir, a persuasão da mensagem (Schiffman e Kanuk 2001, p.17).
}

\title{
3.2. Atitude
}

Segundo Schiffman e Kanuk (2000, p.167), atitude é uma predisposição, que se aprende, levando a pessoa a se comportar de maneira favorável ou desfavorável a respeito de um dado objeto. Ela serve como referência para que um consumidor avalie um produto de maneira positiva ou negativa, proporcionando sua proximidade ou afastamento em relação ao produto. Já para Peter e Olson (2009, p.130), atitude é a avaliação geral de um conceito feita por uma pessoa.

A Figura 2, a seguir, mostra a visão tradicional dos três componentes da atitude, segundo a perspectiva de Engel, Blackwell e Miniard (2000): 
Figura 2: Componentes da Atitude

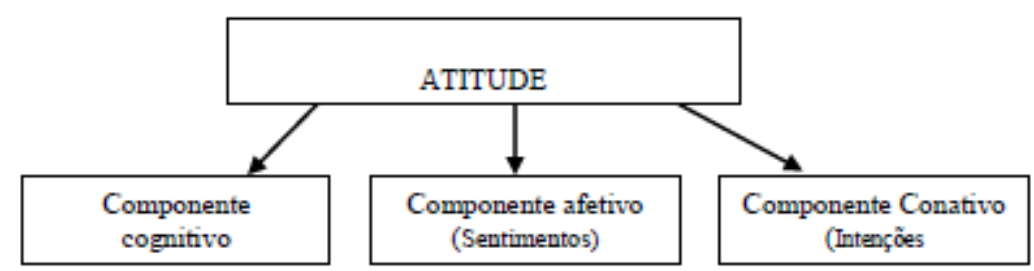

Fonte: Engel, Blackwell e Miniard (2000)

O conhecimento e as crenças de uma pessoa sobre algum objeto de atitude residem no componente cognitivo. O componente afetivo representa os sentimentos de uma pessoa em relação ao objeto da atitude. O componente conativo refere-se às tendências de ação ou comportamentais da pessoa em relação ao objeto da atitude.

Solomon (2002) complementa essa discussão dizendo que o afeto descreve como um consumidor se sente em relação ao objeto da atitude, o comportamento/conativo se refere às suas intenções de agir em relação a ele e a cognição é o que ele acredita ser verdadeiro em relação ao objeto da atitude.

Segundo Peter e Olson (2005), o sistema cognitivo envolve processos de compreensão, avaliação, planejamento, decisão e pensamento, tendo duas funções principais: a primeira refere-se a interpretar experiências pessoais e tirar sentido delas, e a segunda relaciona-se a identificar objetivos e ações para se alcançar esses objetivos. O sistema afetivo se relaciona com o cognitivo, porém, conseguem ser interdependentes. Emoções, sentimentos, humores, avaliações de sentimentos são interpretados pelo sistema cognitivo, assim como conhecimento, significado e crenças sobre algo afetam o sistema afetivo.

\subsection{Heurística}

O termo heurística é definido por Schiffman e Kanuk (2000, p.397) como a criação de "atalhos para as regras de decisão para facilitar o processo de tomada de decisão na hora de comprar um produto". Solomon (2002, p.355), por sua vez, complementa essa reflexão definido a heurística como sendo as "regras mentais que levam a uma decisão rápida" do consumidor.

Para Peter e Olson (2009, p.174), a heurística é uma simples proposição "se.... então", que associa um evento a uma ação apropriada, podendo, contudo, existir três tipos de heurística. O primeiro tipo é a heurística de busca, que consiste em um procedimento simples para procurar informações relevantes a 
um objetivo. Já a heurística de avaliação é um procedimento de avaliar e ponderar as crenças com base no objetivo que será enfocado no processo de resolução de problemas. O terceiro tipo, a heurística de escolha, é um procedimento simples que compara avaliações de ações alternativas com o objetivo de escolher uma delas.

Segundo Hoyer e MacInnis (2011, p.135), os consumidores podem auxiliar seus julgamentos ao formarem heurísticas, que são regras gerais simples, fáceis de evocar e exigem pouca análise. O exemplo que os autores fornecem é o de que os consumidores podem usar a heurística "se é uma marca conhecida deve ser boa" para inferir que marcas com anúncios mais frequentes têm melhor qualidade. 


\section{Métodos e procedimentos de coleta e de análise de dados do estudo}

O capítulo a seguir apresenta os procedimentos metodológicos utilizados na coleta de dados da pesquisa. Assim, discute o tipo de pesquisa, a seleção dos sujeitos, a coleta de dados, o tratamento de dados e as limitações do método.

\subsection{Tipo de pesquisa}

A presente pesquisa se caracteriza por ser do tipo exploratório. A pesquisa exploratória, segundo Gil (2002), tem como objetivo gerar maior conhecimento e familiaridade com o problema, para torná-lo mais explícito ou construir hipóteses. Essas pesquisas envolvem levantamentos bibliográficos, entrevistas com pessoas que tiveram experiências práticas com o problema pesquisado, e análise de exemplos que "estimulem a compreensão".

A pesquisa também é de cunho qualitativo, pois se preocupa com o aprofundamento da compreensão de um grupo social e suas atitudes. Os pesquisadores que se utilizam desse tipo de pesquisa buscam explicar o porquê das coisas, descobrindo e determinando sentimentos, mas não conseguem quantificar valores, pois os dados analisados são "não-métricos", ou seja, não tem como medir, são dados de interação entre entrevistador e entrevistado, para comparação de respostas. Dentro da pesquisa qualitativa, o entrevistador é sujeito e objeto da sua pesquisa, e o desenvolvimento da pesquisa é imprevisível, pois o conhecimento do pesquisador é limitado e as respostas dependem de inúmeras variáveis que podem aparecer (Aaker, 2001).

Segundo Gerhardt e Silveira (2009), as características principais da pesquisa qualitativa são: objetivação do fenômeno, hierarquizar sobre as ações, descrever, compreender e explicar os fenômenos, observar diferenças entre o mundo social e o mundo natural e buscar os melhores resultados possíveis em relação aos seus dados empíricos. 


\subsection{Seleção de Sujeitos}

Para fazer esta pesquisa, foram selecionados e entrevistados 15 consumidores. O critério de participação na pesquisa requeria que fossem consumidores que tivessem vivido numa época sem internet, quando o acesso à informações de artistas e repertório era restrito que frequentassem lojas de discos e tivessem comprado o produto por impulso somente pelos atributos da capa. Como cerca de $73 \%$ dos entrevistados nasceram nas décadas de 1960 e 1970, puderam vivenciar essa experiência

Alguns entrevistados foram acessados por meio de indicações, enquanto outros foram pessoas próximas ao pesquisador, portanto, de fácil acesso. Ainda, houve um grupo de entrevistados que foi escolhido de forma aleatória, em lojas especializadas de música.

No Quadro 3, são apresentados os perfis dos entrevistados:

Quadro 3: Entrevistados da pesquisa

\begin{tabular}{|c|c|c|c|}
\hline $\begin{array}{l}\text { Número do } \\
\text { Entrevistado }\end{array}$ & $\begin{array}{c}\text { Data de } \\
\text { Nascimento }\end{array}$ & Profissão & Grau de Educação \\
\hline 1 & $10 / 10 / 1970$ & $\begin{array}{c}\text { Professor } \\
\text { Universitário }\end{array}$ & Superior Completo \\
\hline 2 & $28 / 01 / 1994$ & Administradora & Superior Cursando \\
\hline 3 & $12 / 11 / 1973$ & $\begin{array}{c}\text { Comerciário } \\
\text { Desempregado }\end{array}$ & Superior Completo \\
\hline 4 & 05/08/1983 & $\begin{array}{l}\text { Ex-Designer e } \\
\text { músico }\end{array}$ & Superior Completo \\
\hline 5 & 02/02/1971 & $\begin{array}{l}\text { Redator Chefe de } \\
\text { uma Revista de } \\
\text { Música }\end{array}$ & Superior Completo \\
\hline 6 & $07 / 05 / 1988$ & Nutricionista & Superior Completo \\
\hline 7 & 10/05/1977 & $\begin{array}{c}\text { Criador e editor } \\
\text { da revista Poeira } \\
\text { Zine }\end{array}$ & Superior Completo \\
\hline 8 & $21 / 03 / 1970$ & Blogueiro & Superior Completo \\
\hline 9 & $19 / 08 / 1984$ & $\begin{array}{l}\text { Analista de } \\
\text { Marketing }\end{array}$ & Superior Completo \\
\hline 10 & $24 / 11 / 1969$ & Administradora & Superior Completo \\
\hline 11 & $09 / 05 / 1971$ & Ator & Superior Completo \\
\hline 12 & $16 / 08 / 1973$ & Economista & Superior Completo \\
\hline 13 & 05/09/1970 & $\begin{array}{l}\text { Analista de } \\
\text { Marketing }\end{array}$ & Superior Completo \\
\hline 14 & $02 / 11 / 1960$ & $\begin{array}{l}\text { Jornalista, Crítico } \\
\text { e Produtor Musical }\end{array}$ & Superior Completo \\
\hline 15 & $26 / 02 / 1969$ & Analista do $\mathrm{RH}$ & Superior Completo \\
\hline
\end{tabular}




\subsection{Coleta de dados}

Quando uma pesquisa é planejada, existe uma variedade de métodos a serem considerados, que podem ser classificados em relação ao uso de fontes primárias ou secundárias de dados. Aaker (2001, p.99) diz que dados primários "são coletados especialmente para determinada pesquisa", por serem extraídos direto da fonte. Quanto a dados secundários, o autor aponta que são:

\footnotetext{
Aqueles que foram coletados por pessoas ou agências para outros propósitos que não a resolução do problema específico que se tem em mãos. Eles constituem os meios mais baratos e fáceis de acesso às informações, ou seja, a primeira coisa que um pesquisador deve fazer é verificar a disponibilidade de dados secundários sobre o tópico de seu estudo (AAKER, 2001, p.130).
}

A técnica para a coleta de dados do presente estudo foi o de entrevistas em profundidade, com roteiro semiestruturado. As entrevistas foram presenciais, realizadas tanto em lojas específicas que vendem discos, para conversar com os consumidores de música, quanto em outros locais convenientes para os participantes da pesquisa. As entrevistas foram gravadas, com o consentimento dos entrevistados, para uma futura análise.

Visando complementar os dados primários, foram analisados dados secundários em livros, artigos e revistas relacionados ao tema da pesquisa, que contribuíssem com o resultado pretendido.

Para guiar as entrevistas, foi elaborado um roteiro (vide Apêndice 1), dividido em duas partes. A primeira parte abordava as experiências pessoais dos entrevistados com álbuns. Desejava-se saber, por exemplo, se já haviam comprado um disco somente pelo apelo da capa; como foi a primeira vez que compraram um álbum dessa forma; o que tinha chamado sua atenção na capa; se existia alguma circunstância especial em torno da compra do disco; se sabiam quem era o artista quando compraram; e se associaram a capa à música em si. Ainda, foi perguntado se o entrevistado tem o hábito de comprar somente pela capa atualmente, mesmo com a popularização da Internet, e se a capa é um elemento importante para se conhecer um novo artista ou uma nova banda.

A segunda parte do roteiro continha perguntas sobre diferentes capas de discos e as reações dos entrevistados a elas. Foram selecionadas oito capas, sendo seis de bandas desconhecidas e duas de bandas conhecidas pelo grande 
público, sendo feitas cinco perguntas a respeito delas. A primeira era uma pergunta filtro, para definir se o consumidor já tinha visto a capa do álbum anteriormente. A segunda questionava o que chama mais a atenção do consumidor ao olhar a capa analisada. A terceira perguntava o que o consumidor pensava a respeito da música do artista/banda quando se observa a capa. A quarta questão era referente ao estilo musical que o entrevistado acreditava ser o do artista do disco. A última perguntava qual capa o entrevistado estava mais propenso a comprar.

\subsection{Tratamento de dados}

A partir das entrevistas, os relatos dos entrevistados foram organizados para, em seguida, serem analisados.

Inicialmente, os dados foram organizados em temas e os relatos que correspondiam a esses eram agrupados neles. Esses temas foram definidos a partir do roteiro de entrevistas, de forma a facilitar esse processo de organização.

Em seguida, os relatos foram comparados entre si e com a revisão de literatura, a fim de encontrar semelhanças e diferenças. Esses processo permitiu chegar às categorias de análise, apresentadas no próximo capítulo.

\subsection{Limitações do método}

Como qualquer método de pesquisa, existem vantagens e desvantagens naqueles escolhidos para o presente estudo.

Segundo Mattar (2005, p.159), as desvantagens dos dados primários são que não conseguimos quantificar previsões e antecipações de comportamentos futuros declarados pelos próprios entrevistados. Outro ponto que Mattar (2005) aborda é que se as pessoas se comportassem de acordo com as intenções, seria o melhor tipo de dado a ser coletado, pois haveria maior credibilidade na fonte. Por sua vez, Malhotra e Rocha (2005, p.74) indicam que as desvantagens dos dados secundários podem ser: examinar erros em abordagem, concepção da pesquisa, coleta de dados, análise de dados e relatório; atualidade dos dados, ou seja, o prazo entre coleta e publicação dos dados, frequência das 
atualizações; ter uma confiabilidade do respondente em relação à experiência, credibilidade, reputação e confiar na fonte em si.

As desvantagens de entrevistas em profundidade, segundo Malhotra e Rocha (2005), referem-se à falta de estrutura da entrevista, que faz com que os resultados sejam suscetíveis à influência do entrevistador, de cuja habilidade depende a qualidade e integridade dos resultados. A duração da entrevista, combinada com o alto custo, significa que um projeto pode ser conduzido apenas com um número pequeno de entrevistas em profundidade. Contudo, o detalhamento do conteúdo que a entrevista em profundidade permite sobrepõese às desvantagens do método.

De acordo com Gerhardt e Silveira (2009), o pesquisador deve estar atento para alguns limites e riscos da pesquisa qualitativa, tais como: excessiva confiança do investigador como instrumento de coleta de dados, falta de detalhes sobre os processos através dos quais as conclusões foram alcançadas, falta de observação de aspectos diferentes e de enfoques diferentes, sensação de dominar profundamente seu objeto de estudo, envolvimento do pesquisador com seus entrevistados de maneira a prejudicar as respostas finais.

As escolhas das capas para a pesquisa foram feitas aleatoriamente. Buscou-se bandas que não fossem tão populares, para que não houvesse uma identificação anterior do entrevistado com a banda. Porém, como foram escolhidas duas bandas mais conhecidas, "Focus" e "Premiata Forneria Marconi", era necessário obter duas capas alternativas caso alguém reconhecesse as capas. As capas, como um todo, tinham que conter elementos gráficos, como cores e figuras, que chamassem atenção dos consumidores para obterem uma primeira boa impressão. Apesar de o mercado brasileiro conter ótimas capas, somente foram analisadas capas internacionais, pois havia maior chance do público entrevistado não conhecer as bandas escolhidas, por estarem muito longe do mercado em que elas se inserem. 


\title{
5 Análise dos resultados
}

Este capítulo, organizado em duas seções, apresenta e discute os principais resultados obtidos na pesquisa. Primeiramente, discutem-se as experiências pessoais dos entrevistados com discos e suas capas. Em seguida, apresentam-se os principais fatores que fazem os entrevistados sentirem atração ou afastamento de capas de discos.

\subsection{Experiências pessoais com discos e suas capas}

Este item discute as experiências pessoais dos entrevistados com discos e suas capas. Está dividido em três subitens, a saber: experiência pessoal inicial, fatores de encantamento com a capa e importância do consumo da capa do disco.

\subsubsection{Experiência pessoal inicial}

Quase todos os entrevistados alegaram já ter comprado álbuns por impulso, muitas vezes a partir das capas dos discos. Segundo um entrevistado, ir à loja de discos era um evento semanal:

\begin{abstract}
Lembro que, durante a década de 1980, quando era jovem, comprava quase semanalmente discos de vinil na Woodstock Discos, em São Paulo. O dono da loja, que é meu amigo até hoje, costumava colocar uns bilhetes dentro das capas dos lançamentos com o conceito dos discos e deixava na prateleira, para quem quisesse pegar e ter uma "descoberta". Vários discos 'comprei' por indicação dele, mas às vezes, a arte da capa falava mais alto, nem perguntava o que achavam dela, me levava somente pela magia que a capa me passava naquele momento.
\end{abstract}

Todavia, nem sempre essa forma de compra resultou em experiências positivas. Uma entrevistada, por exemplo, contou a seguinte experiência:

Tinha por volta de uns 6 anos de idade, época inocente que a criança fica apaixonada por tudo que vê. Estava numa fase de gostar de anjos, ia na Igreja com meus pais e via aquelas estátuas e ficava deslumbrada, e, na mesma época, existia uma 
loja que usava a temática anjo. Um belo dia, estava com meu pai andando pela rua, e ele decidiu ir na loja Modern Sound, que ficava em Copacabana. Era uma loja imensa, e vi um pôster que eu fiquei olhando por uns 10 minutos, era uma pintura de um anjo incrível, que era a capa de um CD da banda Angra, chamado "Rebirth" (Figura 3), mas eu não tinha a menor ideia do quem era ou do que se tratava. Só comprei, e resolvi ouvir, mas odiei, a música não tinha nada a ver com aquele anjo da capa, não é mesmo meu estilo de música, e acho que até joguei fora o $C D$, de tão frustrada que eu fiquei, mas me lembro até hoje dessa experiência, ficou marcada.

Outro exemplo em que a figura de um anjo na capa de um disco é citada como gerador de atenção é a do álbum "Sad Wings of Destiny" da banda Judas Priest (Figura 4). Segundo o entrevistado 14, é uma "magnífica capa", que mostra uma pintura sobre a queda do anjo Lúcifer. De acordo com o entrevistado, a capa é "absurdamente colorida" para os padrões de capas da época, o que Ihe chamou bastante atenção, e resultou em sua compra.

Em ambos os casos citados, o anjo é visto pelos entrevistados como uma figura forte, enigmática e que representa vários significados na cultura em geral. Isso pode significar que os entrevistados usaram o conceito de semiótica, conforme definido por Solomon (2011), pois deram ao anjo vários significados.

Figura 3 - Angra, "Rebirth"

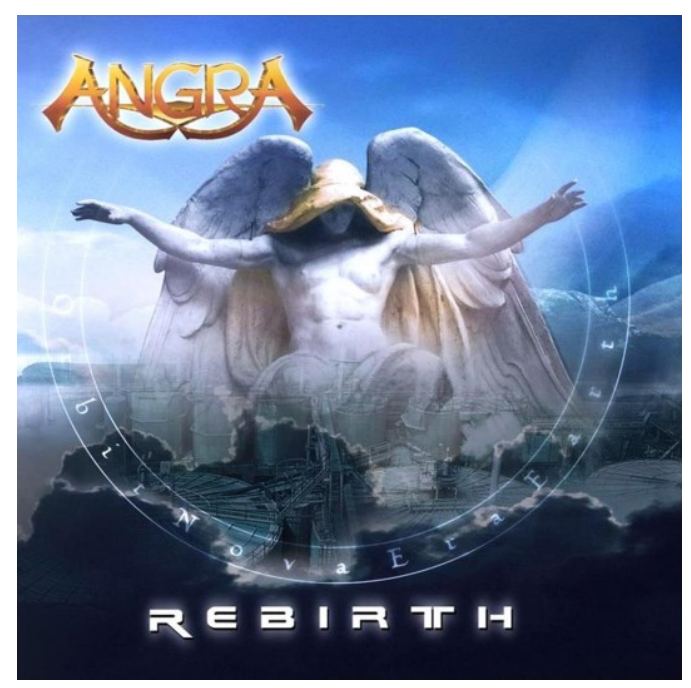

(Fonte: Google Imagens) 
Figura 4 - Judas Priest, "Sad Wings of Destiny"

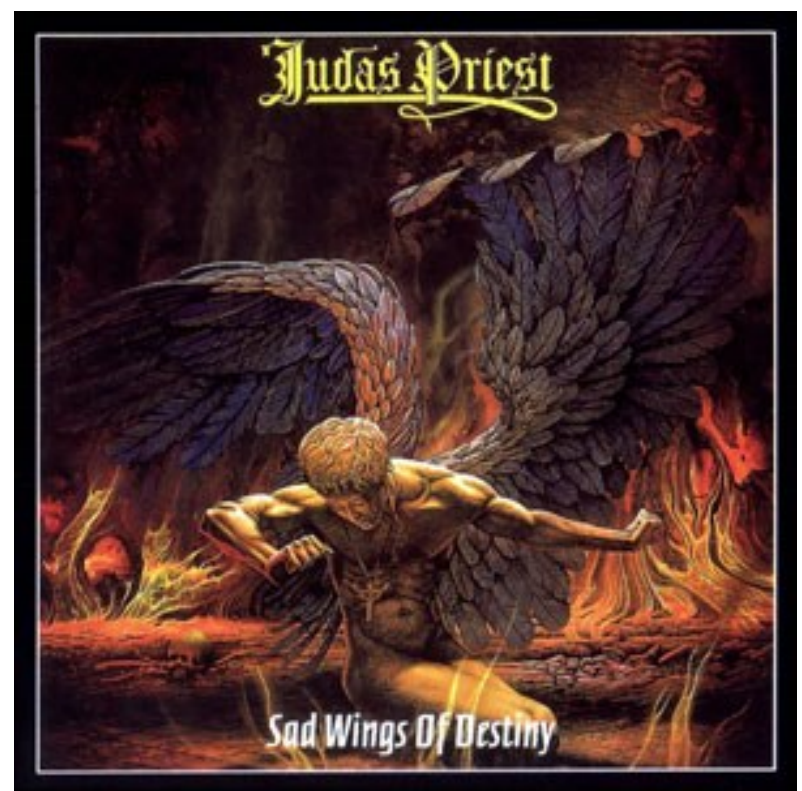

(Fonte: Google Imagens)

Ainda utilizando o relato do entrevistado 14 , ele cita o álbum da banda Dust, chamado "Hard Attack", que contém uma pintura de três vikings brigando no alto de uma montanha. O que chamou sua atenção à capa foi o fato de ela apresentar essa temática, no início dos anos 1970, época em que discussões dessa natureza estavam em voga, por causa do sucesso dos livros de J.R. Tolkien, recém redescoberto pela cultura americana. Para o entrevistado, a capa representava algo "incrível", porque também remetia à revista de quadrinhos adulta "Heavy Metal", que utilizava temas como fiç̧ão científica e fantasia como tema de suas histórias. Ainda, o mesmo entrevistado deu como exemplo outra capa, a do artista Jackson Browne (Figura 5), que na época de seu lançamento tinha o nome de "Saturate Before Using", e atualmente chama-se "Jackson Browne". O que chamou a atenção do consumidor foi o fato da capa ser uma sátira às embalagens de sopas americanas e a Andy Warhol, que fez sucesso com pinturas dessas embalagens no final dos anos 1960. 
Figura 5 - Jackson Browne, "Saturate Before Using"

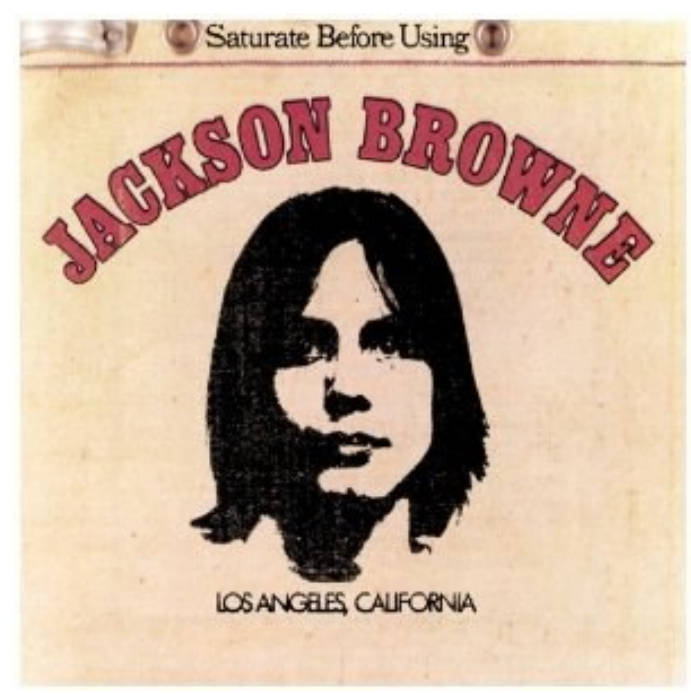

(Fonte: Google Imagens)

Já o entrevistado 1 disse que comprou discos cujas capas o traziam boas lembranças da infância:

Quando era criança, adorava passar horas na praia, brincando, sozinho, com amigos, com meus pais, achava incrivel aquela imensidão de areia e aquele mar infinito. Um dia, já grande, vi a capa de um álbum do Stevie Wonder, que é um clássico até hoje, o "Songs in the Key of Life" (Figura 6), e comprei, por um motivo bem simples: toda vez que eu vejo essa capa, eu me recordo dos dias de brincadeira da praia. Acho que o tom laranja e os "círculos" em espiral presentes na capa, me lembram o sol que fazia na praia, o calor, aquelas brincadeiras de colocar as conchas no ouvido para ouvir o barulho do mar, tudo que eu tive de positivo quando criança relacionado a praia.

Figura 6 - Stevie Wonder, "Songs in the Key of Life"

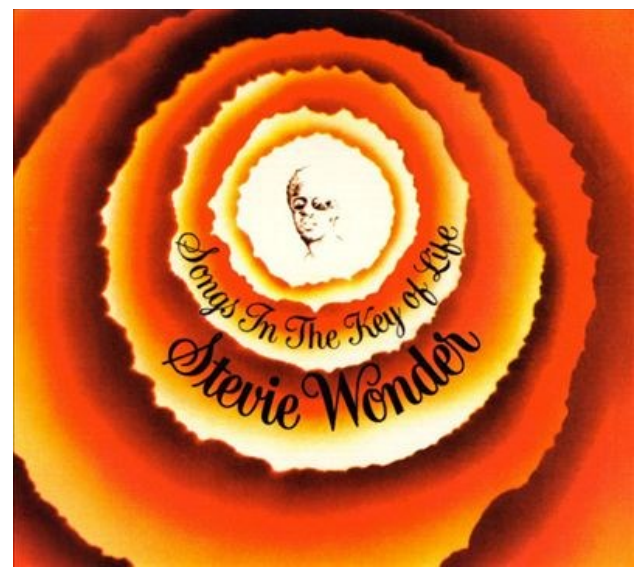

(Fonte: Google Imagens) 
Outro exemplo bastante citado pelos entrevistados como uma capa icônica, que lhes deu vontade de comprar por impulso, é a "grandiosa" capa do album "Somewhere in Time" da banda Iron Maiden (Figura 7).

Figura 7 - Iron Maiden, "Somewhere in Time"

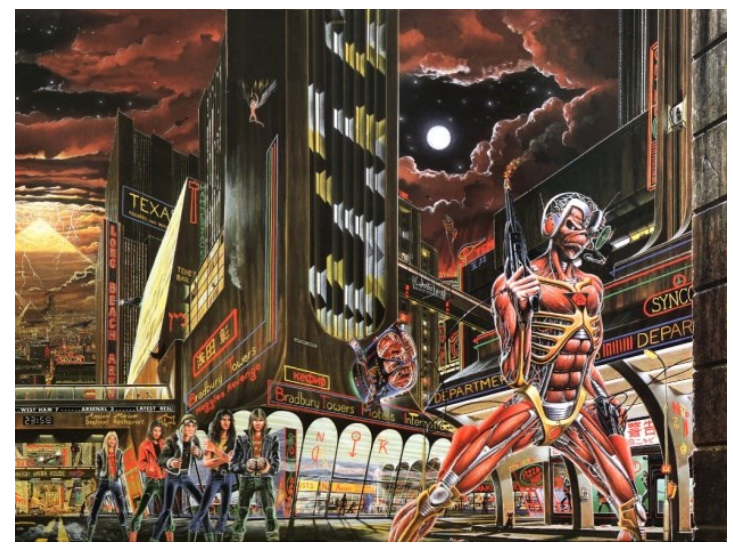

(Fonte: Google Imagens)

A ilustração contém inúmeras referências à banda, como histórias, capas anteriores e personagens retratados nas músicas anteriores, mas também a cultura pop, como livros ("Philip K. Dick"), filmes/cinema ("Blade Runner"), política ("Margareth Thatcher"), futebol ("West Ham 7 × 3 Arsenal”), bares ao redor dos Estados Unidos, entre outras referências. Um entrevistado ficou duas horas tentando listar todas as referências, e diz que até hoje descobre algo diferente que não tinha percebido.

Outros exemplos que foram citados pelos entrevistados de capas que os chamaram atenção por sua simplicidade foram "Nevermind" do Nirvana e "A Hard's Day Night" dos The Beatles. Novidades de diagramação, nos logos das bandas, e desenhos/pinturas/fotos de elementos inusitados também foram descritos como "bem-vindos".

O entrevistado 7 citou a capa do disco "Live Evil" do Black Sabbath, que contém vários personagens contidos nas músicas do próprio disco, como soldados, anjos, guerreiros. Essa temática chamou bastante sua atenção, acrescentando que, mesmo se quem for comprar o disco não souber que é da banda, irá "descobrir" por causa dos personagens. E ainda completou dizendo um pensamento seu da época em que comprou: "Tem um soldado com cara de porco (em referência à música "War Pigs")". 
Outras capas de discos também foram citadas pelos entrevistados como merecedoras de sua atenção, por alguma razão, levando-lhes a comprar o álbum. Nesse grupo, podem ser citados:

- "Wild Dogs", The Rods;

- "Love at First Sting", Scorpions;

- "To Mega Therion", Celtic Frost;

- “Don't break the oath", Mercyful Fate;

- "In the eye of the storm", Roger Hodgson;

- "Nine Lives", Aerosmith;

- "Animals", Pink Floyd;

- "Eternal Dark", Picture;

- "Slide it in", Whitesnake;

- "Blizzard of Ozz", Ozzy Osbourne;

- "Killers", Iron Maiden;

- "Them Changes", Buddy Miles;

- "Back in Black", AC/DC;

- "Forever Changes", Love;

- "Surfing with the alien", Joe Satriani;

- "Christ Illusion", Slayer.

\subsubsection{Fatores de Encantamento com a Capa}

Os entrevistados relataram que as "boas capas" de discos eram aquelas que os faziam lembrar sobre algum evento pessoal ou pensar sobre as mensagens implícitas contidas em cada uma. Mais do que as percepções sobre as capas em si, estava a ideia de que tais estímulos visuais poderiam trazer sentimentos, em sua maioria positivos.

A capa do álbum de Stevie Wonder, citada pelo entrevistado 1, por exemplo, lembrava a praia, e, com isso, fazia o entrevistado lembrar nostalgicamente de sua infância. De acordo com Hoyer e Maclnnis (2011), a cor é um fator importante na percepção visual, sendo a cor laranja associada a calor, que incentiva atividades e gera animação, reafirmando a nostalgia do entrevistado. Já os exemplos dos discos do Angra e o Judas Priest, cujas capas continham um anjo, os entrevistados discutiram como a figura é cheia de significados religiosos. Já a capa do disco do Iron Maiden estava cheia de referências, tanto da banda, quanto de eventos ambientais, que faziam com que seus ouvintes precisassem buscar informações a respeito para entender, 
engajando-o ainda mais com a música. Essa capa envolve vários componentes da atitude, como componentes cognitivos (conhecimento sobre alguma referência), afetivos (sentimentos sobre as referências) e conativos (comportamento do consumidor em relacionar as referências com a capa e com a banda), conforme definição de Engel, Blackwell e Miniard (2000).

Outro exemplo do componente afetivo da atitude foi a capa do disco "Surfing with the Alien" de Joe Satriani (Figura 8). A capa contém um desenho do Surfista Prateado, personagem de quadrinhos, fugindo de seu maior inimigo. Segundo o entrevistado 11, essa capa the lembrou a sua infância, enquanto leitor de quadrinhos:

Quando eu era pequeno, eu sempre lia quadrinhos, e um dos meus favoritos era o "Quarteto Fantástico", e um dos personagens que mais aparecia era o Surfista Prateado, era quase parte do Quarteto em si. E por ironia do destino, um dia estava passando pela rua, passei por uma loja de disco, e vi o Surfista estampando a capa de um disco, e pensei na hora que tinha que comprá-lo, abri um sorriso de ponta a ponta na cara, e falei pro atendente da loja, que eu queria aquele disco daquele pôster. Era um disco do Joe Satriani, e esse tipo de música não era tão comum assim, e eu achei incrível, virei fã na mesma hora.

Figura 8 - Joe Satriani "Surfing with the Alien"

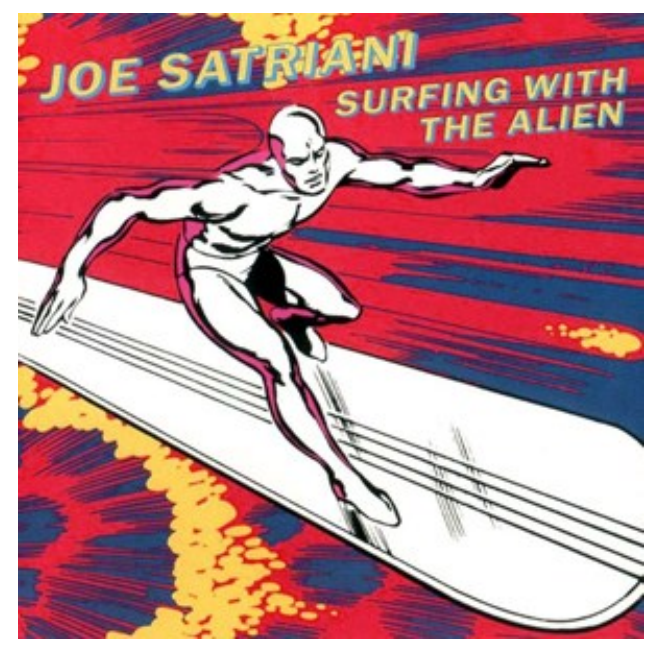

(Fonte: Google Imagens)

Outro fator que levou um entrevistado ao encantamento com uma capa de disco foi a da banda AC/DC, do álbum "Back in Black" (Figura 9), por ser "totalmente preta". A capa representa o luto de uma banda que acabou de perder um integrante, e a vontade de recomeçar e fazer algo novo. Para quem não conhece a banda, parece insignificante, mas para os fãs, ou aqueles que 
estão vendo pela primeira vez, é um impacto grande, explicou o entrevistado. Segundo ele, quando viu a capa pela primeira vez, não entendeu o que significava, achando que era um envelope para proteger o vinil original. Mesmo assim, deu uma chance àquele "vinil estranho". Carvalho (2015) explica que o preto é a terceira cor preferida dos homens, e isso mostra o "fascínio" pela capa. Apesar de o preto ser a soma de todas as cores, não pode ser entendido como uma cor quente ou fria.

\section{Figura $9-A C / D C$ "Back in Black"}

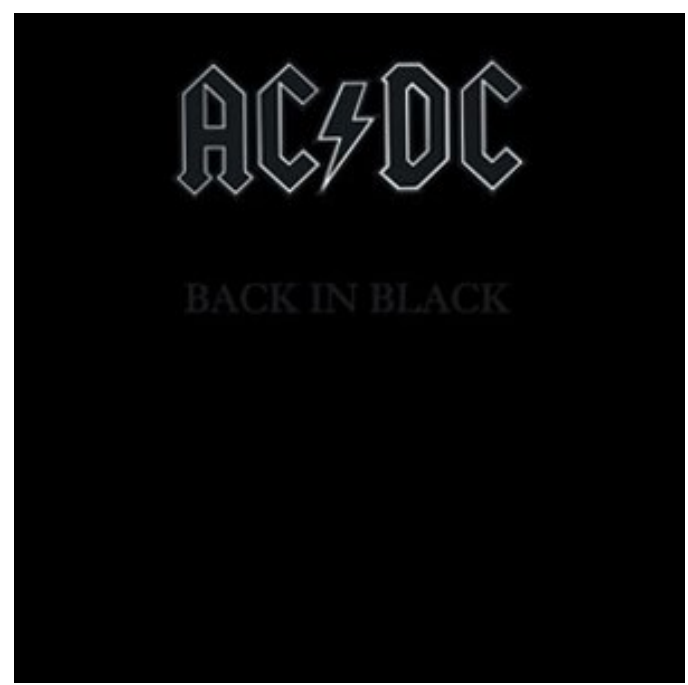

(Fonte : Google Imagens)

\subsubsection{Importância do consumo da capa do disco}

Segundo os entrevistados, capas de discos já foram bastante importantes antigamente, na época do LP, mas não mais atualmente, com o advento e crescimento da Internet. Antes, era bastante comum separar um tempo do dia para sentar e ouvir o álbum inteiro, sem interrupções, abrir e visualizar o encarte, ler e interpretar as letras, conhecer quem são os músicos que fazem parte da banda. Ou seja, antigamente era importante consumir todo o disco (experiência mais profunda, mais conhecimento, mais intimidade, mais sensações, mais curiosidade), e também o material exposto em sua capa. Alguns exemplos de LP's citados pelos entrevistados que proporcionavam essa experiência eram: "The Beatles" (1968), pois trazia consigo um pôster enorme; "Physical Grafitti" (1975) do Led Zeppelin, que continha na capa a foto de um prédio em Nova York, cujas janelas eram vazadas, permitindo que o encarte do álbum pudesse mudar a forma que aparecem na capa, conforme mostrado nas figuras 10, $11 \mathrm{e}$ 12, “Tommy" (1972) do The Who com a London Symphony Orchestra, que 
continha dentro do encarte um grande "pinball" impresso em baixo relevo (Figura 13). Já na era do CD, o álbum "Pulse" (1995) do Pink Floyd tinha uma luz de led piscante em todo o estojo, os álbuns "I" (2009) e "III" (2011) da banda Chickenfoot, que traziam elementos como a capa somente surgindo através do calor humano tocando ela, conforme mostram a Figura 14, ou a capa e a contracapa sendo 3-D, e vindo com um óculos somente para ver detalhes em 3-D, conforme mostram as Figuras 15 e 16.

Figura 10 - Led Zeppelin "Physical Graffiti”

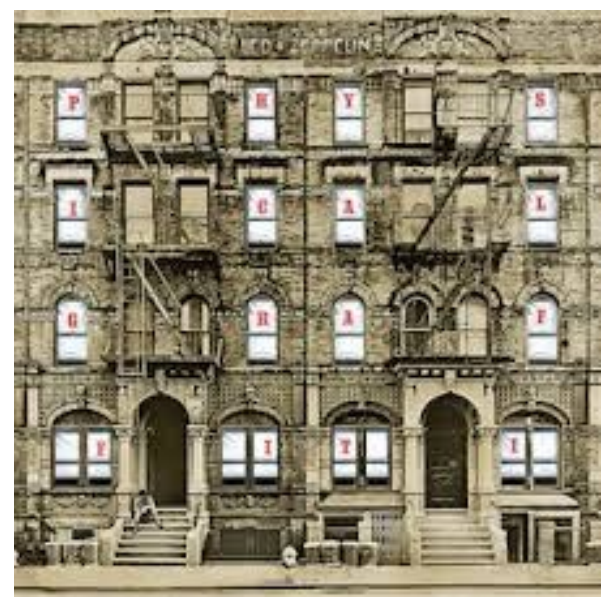

(Fonte: Google Imagens)

Figura 11 - Led Zeppelin "Physical Graffiti”

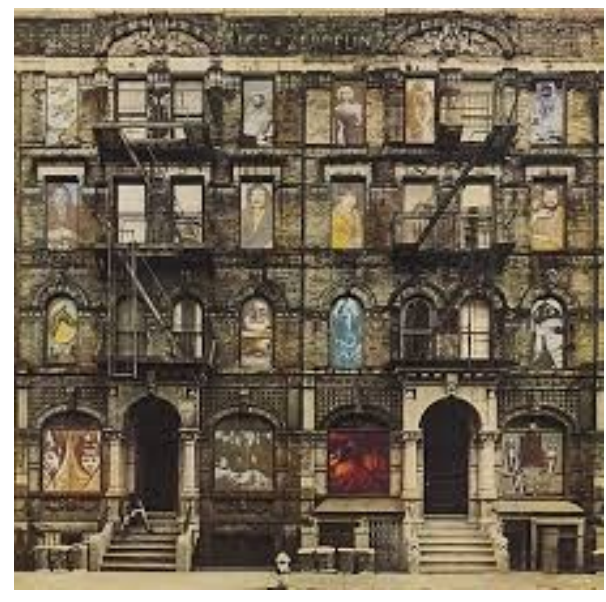

(Fonte: Google Imagens) 
Figura 12 - Led Zeppelin "Physical Graffiti"

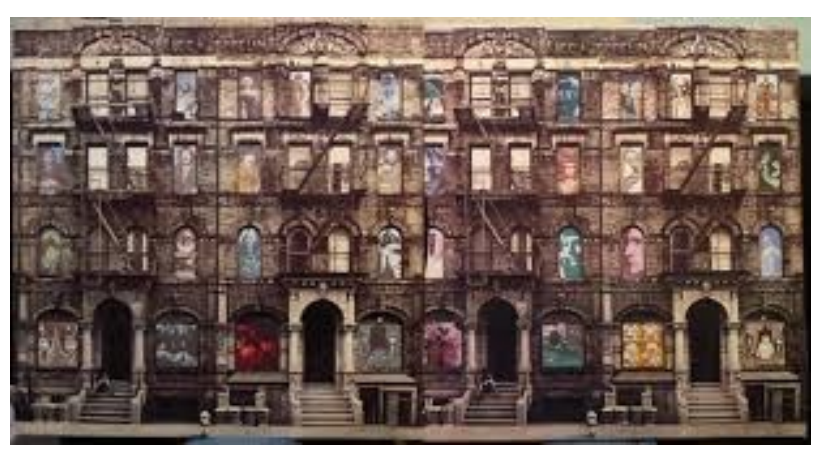

(Fonte: Google Imagens) 
Figura 13 - The Who "Tommy"

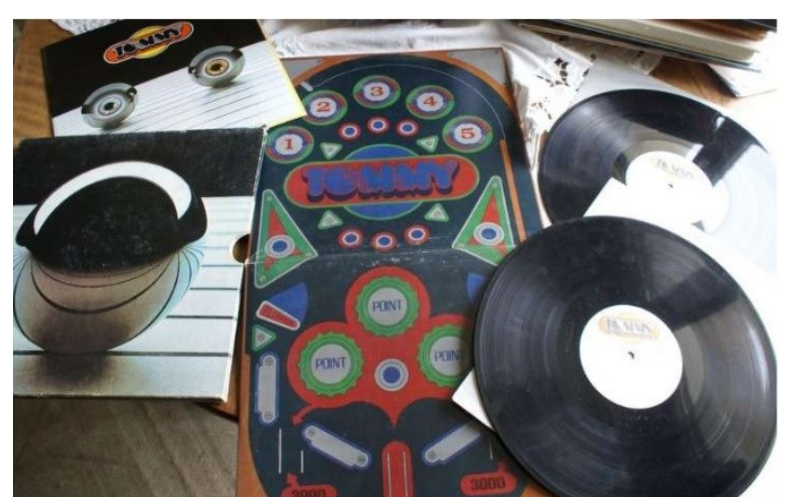

(Fonte: Google Imagens)

Figura 14 - Chickenfoot "I"

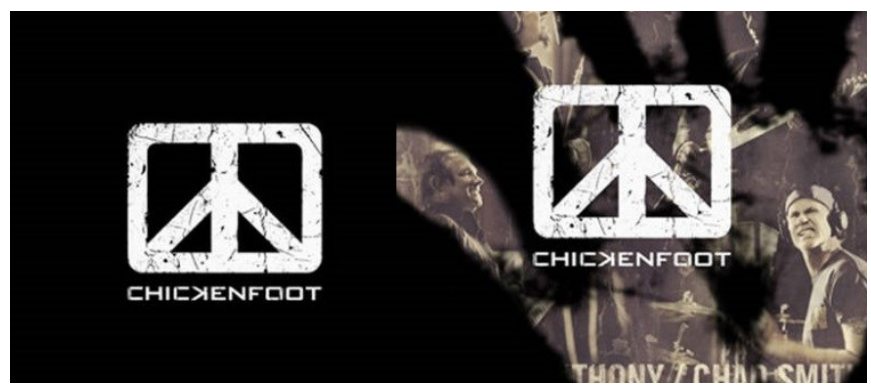

(Fonte: Google Imagens) 
Figura 15 - Chickenfoot "III"

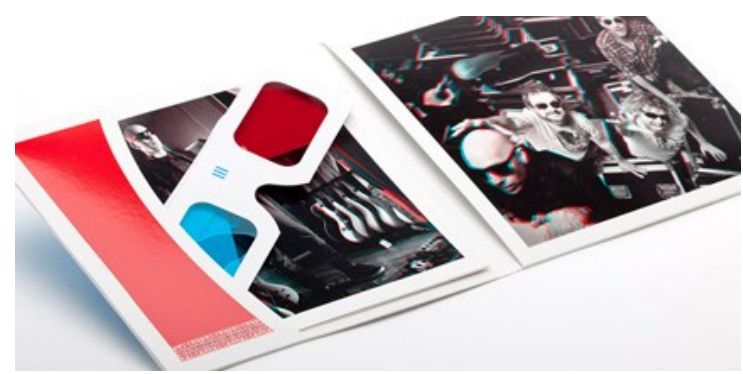

(Fonte: Google Imagens)

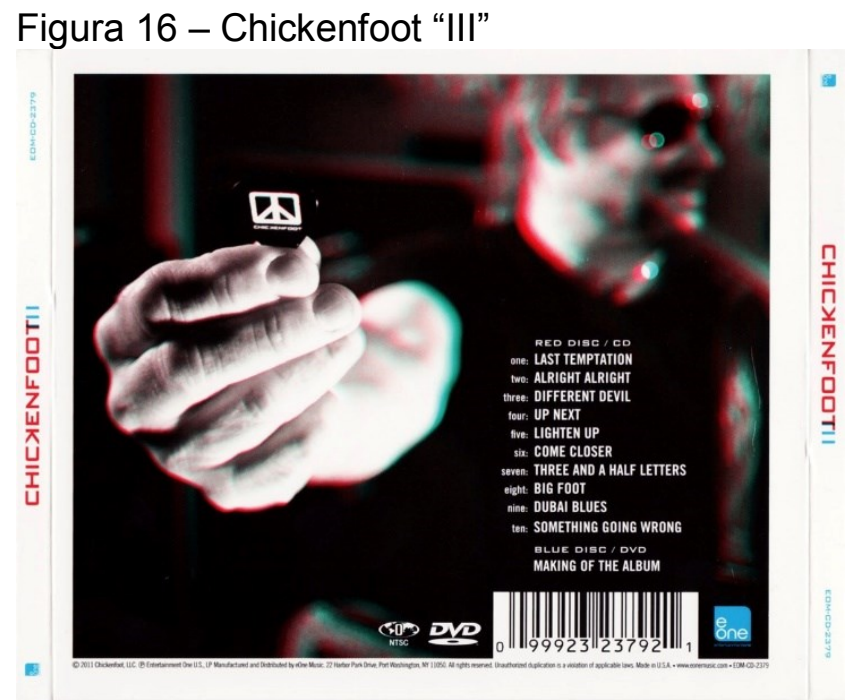

(Fonte: Google Imagens) 
Um dos entrevistados disse que era bastante comum, antigamente, pegar álbuns "de bandas clássicas", como Rush e Pink Floyd, sentar ou deitar em algum lugar, apagar as luzes, e "ouvir de ponta a ponta, sem se preocupar com o mundo externo, como se estivesse vendo um filme no cinema". Esse mesmo entrevistado disse que, hoje em dia, "não se tem mais tempo para música", ou seja, usam-se aplicativos como Spotify ou ITunes Music, que oferecem acesso fácil a diversos estilos e quantidades de músicas, tornando aleatória a busca por músicas, sem haver preocupação com a experiência de ouvi-las. Acaba que escutar música, atualmente, se tornou uma atividade que se faz mais pela praticidade e facilidade, já que se pode ouvir dentro do metrô ou em um churrasco, através do smartphone.

A capa do disco, com a Internet, não é mais um acessório da música . No máximo, pode-se ver a capa na tela de algum computador ou dispositivo móvel, porém sem tocá-la ou ler em detalhes seu conteúdo. Isso acaba gerando baixo envolvimento do consumidor, que perde o acesso a informações sobre a música e a banda, tornando a música descartável. A capa do disco, portanto, tem uma importância maior do que somente anunciar o artista; serve para aproximar o ouvinte do projeto musical.

\subsection{Análise sobre capas de discos}

Nessa segunda etapa da pesquisa, foram selecionadas oito capas de discos, sendo seis capas de artistas novos, dos anos de 2015 e 2016, e duas capas de artistas conhecidos, com carreiras bem sucedidas, da década de 1970. Caso o entrevistado conhecesse as duas capas dos artistas conhecidos, havia duas outras capas de discos, também de artistas conhecidos, para servir como alternativas.

O objetivo dessa parte da pesquisa era tentar reproduzir o que seria o primeiro contato dos entrevistados com um disco que desconhecessem, de forma a entender quais elementos mais chamam a atenção e suas interpretações sobre o que significam.

As capas apresentadas aos entrevistados eram as seguintes: 


\section{Capa 1)}

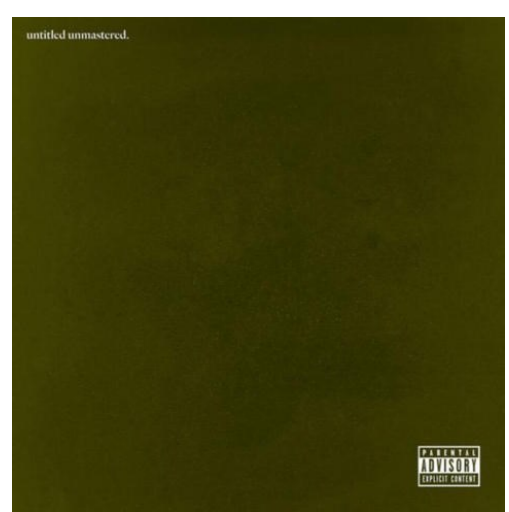

Artista: Kendrick Lamar

Album: untitled unmastered

Lançado: 2016

Estilo: Hip-Hop 


\section{Capa 2)}

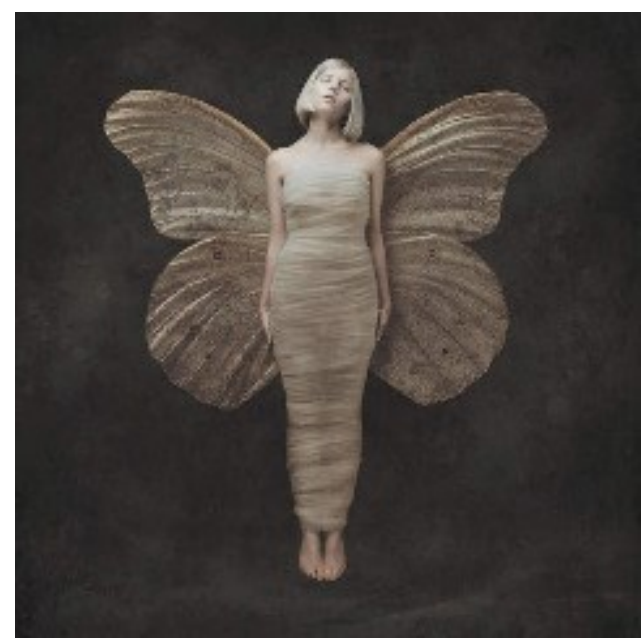

Artista: Aurora

Album: All My Demons Greeting Me As A Friend Lançado: 2016

Estilo: Synthpop

\section{Capa 3)}

Artista: Bethel Music

Album: Have It All Live

Lançado: 2016

Estilo: Música Gospel 


\section{Capa 4)}

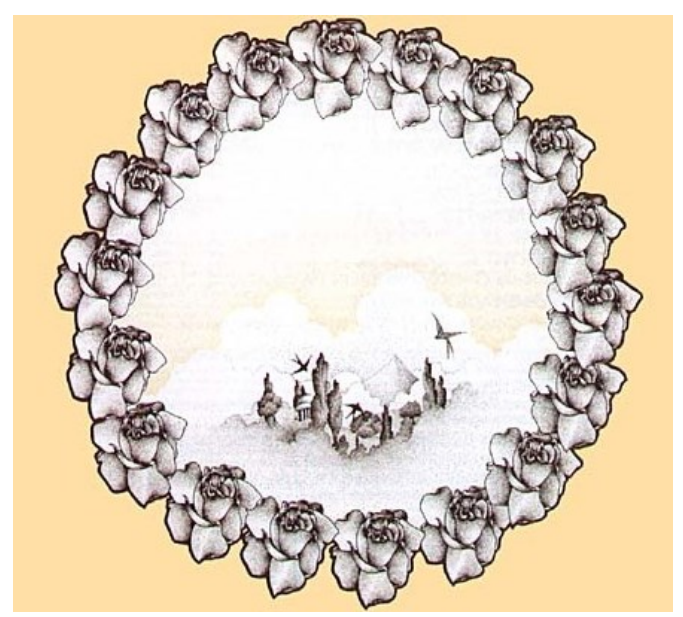

Artista: Premiata Forneria Marconi

Album: Photo of Ghosts

Lançado: 1973

Estilo: Rock progressivo

\section{Capa 4 alternativa)}

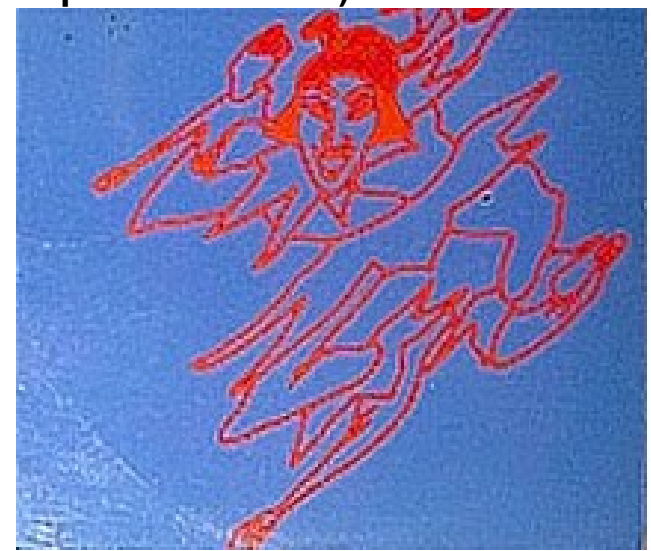

Artista: Alex Harvey

Album: Joker is Wild

Lançado: 1972

Estilo: Rock 


\section{Capa 5)}

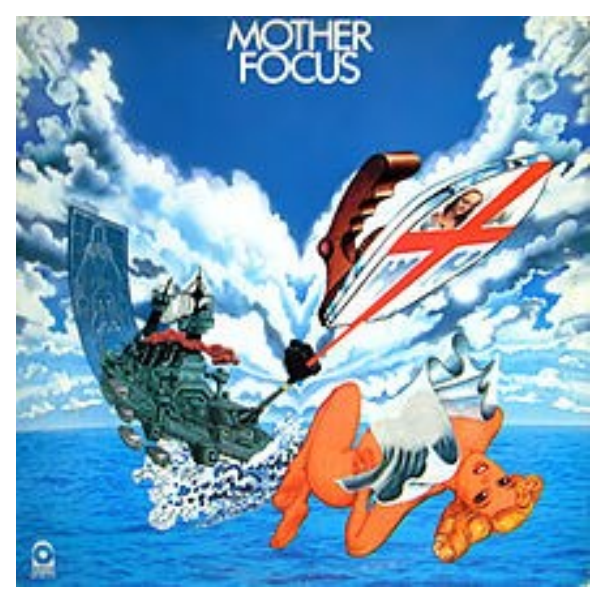

Artista: Focus

Album: Mother Focus

Lançado: 1975

Estilo: Funk, Jazz Pop, Rock Instrumental e Rock progressivo

\section{Capa 5 alternativa)}

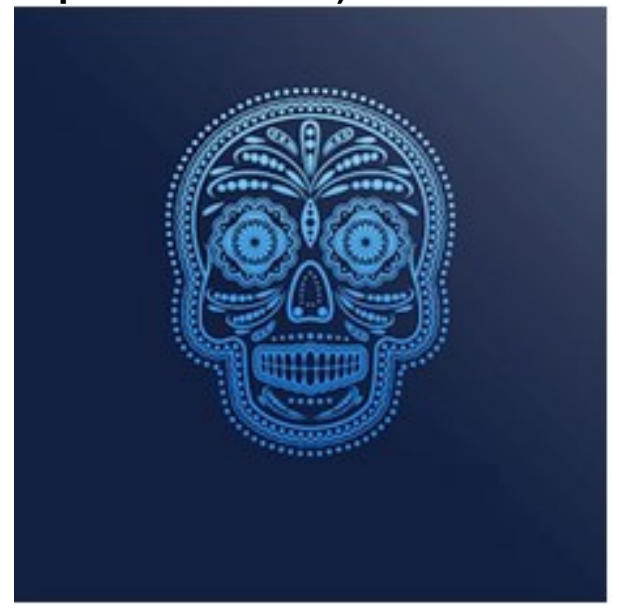

Artista: Tin Spirits (ex-guitarrista do XTC)

Album: Wired to Earth

Lançado: 2012

Estilo: Rock 
Capa 6)

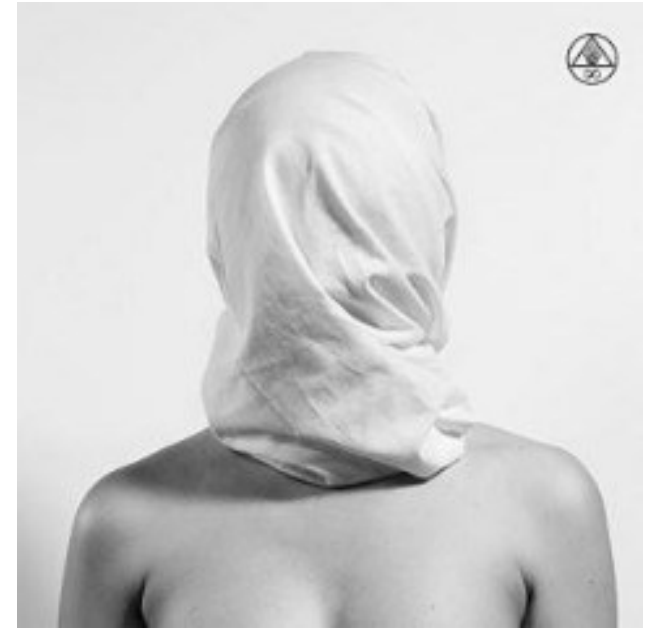

Artista: Ketzer

Album: Starless

Lançado: 2016

Estilo: Metal

\section{Capa 7)}

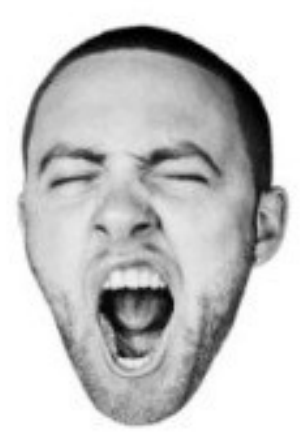

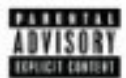

Artista: Mac Miller

Album: Good AM

Lançado: 2016

Estilo: Hip Hop 


\section{Capa 8)}

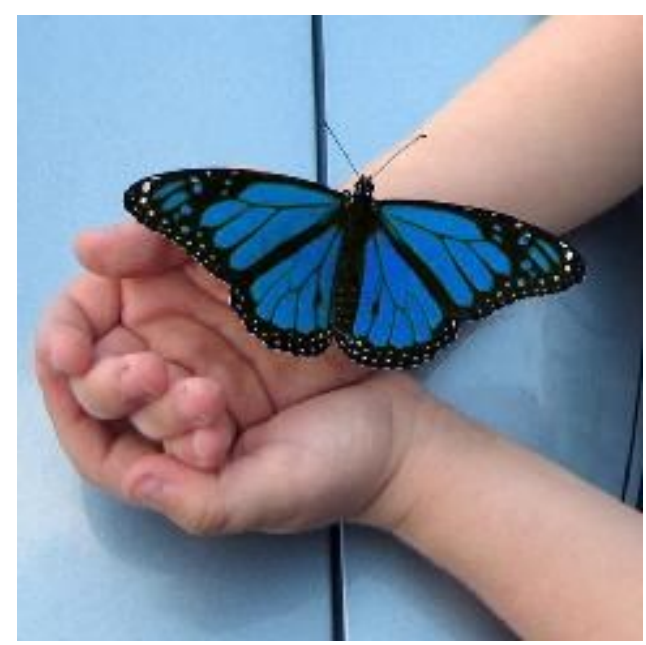

Artista: Hardy Kuster

Album: Mariposa Azul

Lançado: Música Eletrônica

Estilo: 2016

Todas as capas acima foram pesquisadas em um website de download de álbuns denominado "New Album Releases".

\subsubsection{Percepção sobre capas de discos}

No caso das capas de discos, o estímulo visual é o elemento que primeiro capta a atenção de consumidores. Uma bela imagem, por exemplo, pode significar maior aptidão a gostar do disco, devido à atração natural ao estímulo, o que, por conseguinte, pode resultar em uma compra, mesmo sem maiores conhecimento sobre o artista do álbum. As capas de discos com uma borboleta estampada (discos "All my demons greeting me as a friend" e "Mariposa Azul", das bandas Aurora e Hardy Kuster) foram facilmente atentas e interpretadas pelos entrevistados, com a alegação de que tais insetos são bonitos e, além disso, apresentam uma simbologia admirada por todos, em termos de sua evolução natural de uma larva a um animal de grande beleza.

As cores das capas de disco também chamam a atenção dos entrevistados. A capa do disco de Kendrick Lamar, que é totalmente verde, não despertou interesses nos participantes da pesquisa, apesar de essa cor ser a segunda mais favorita por homens e terceira por mulheres, segundo Carvalho (2015), e ser denominada uma cor fria, e por ela ser mais tranquilizante e relaxante (HOYER; MACINNIS, 2011). Porém, a capa do disco de Hardy Kuster, que contém a mariposa/borboleta azul, chamou bastante atenção dos 
entrevistados, diversos alegando ser essa a sua cor favorita. É importante destacar, também, que não foi somente a mariposa/borboleta que chamou a atenção na capa; as mãos onde está pousado o inseto também foram bastante citadas, por não se saberem de quem seriam, de um bebê?, uma criança ou um adulto.

Outra capa bastante comentada pelos entrevistados foi a do disco "Mother Focus", da banda Focus. Segundo eles, a imagem remete a algo "bastante psicodélico" e lembra o trabalho do pintor surrealista Salvador Dali. As cores, nesse caso, também foram ressaltadas, porém, com menos foco do que as imagens. A banda em questão é do estilo rock progressivo, sendo comum dentro do gênero que capas de discos sejam coloridas e psicodélicas.

É possível entender, portanto, que somente um estímulo visual com uma cor parece não ser suficiente para chamar a atenção dos entrevistados para a capa dos discos. Somente com uma combinação de cores e outros elementos visuais é que a capa se torna atrativa, ainda mais quando a imagem ilustrada gera questionamentos por parte do consumidor sobre seus significados.

As interpretações dos entrevistados quanto às imagens das capas dos discos parecem seguir os princípios da semiótica, conforme indicam Solomon (2011) e Schiffman e Kanuk (2001). A capa do disco da artista Aurora, que mostra a própria cantora vestida como uma borboleta, é um exemplo disso. Com base na imagem da capa, os entrevistados fizeram analogias entre "transformações", "felicidade", "beleza", "renovação" e "natureza" com a própria artista, que parece uma menina jovem, em plena evolução na vida.

Em relação à capa do disco "Mariposa Azul" da banda Hardy Kuster, que também contém uma borboleta, a interpretação diferiu. Nesse caso, os entrevistados imaginavam uma metamorfose, porém dos seres humanos ao longo da vida, seja física ou socialmente. Viam na borboleta um símbolo de "sorte", que poderia ser transferido a eles caso possuíssem o disco.

Outra imagem que trouxe interpretações de natureza distintas foi a da capa do disco "Have it all Live", da banda Bethel Music, que apresentou um coração, como um órgão, e não um desenho representativo do amor. Enquanto alguns entrevistados sentiram desconforto e desviavam o olhar, sem sequer tentar interpretar o que significava, por ser algo "muito cru", outros apreciaram sua simplicidade, imaginando que o artista usava a imagem para mostrar que as músicas do disco "vem da alma, do coração". Parece, dessa forma, para esse segundo grupo de entrevistados, que o artista foi feliz em sua escolha de capa de disco, pois retratou positivamente a "origem" de sua música, especialmente 
por ser do estilo gospel. Nesse estilo musical, fala-se de e para Deus, dessa maneira, a única forma de se transmitir essa ideia seria pela alma, pois somente assim garante-se falar "a verdade".

\subsubsection{Atitude sobre capas de discos}

Schiffman e Kanuk (2000) apontam que a atitude é uma predisposição que se aprende, levando a pessoa a se comportar de maneira favorável ou desfavorável a respeito de um objeto. Assim, é possível observar alguns estímulos que levam os entrevistados a terem atitudes positivas em relação às capas analisadas.

A borboleta, como componente das capas dos artistas "Aurora" e "Hardy Kuster", é vista de maneira positiva pelos entrevistados. O mesmo pode-se dizer sobre a capa do artista "Bethel Music", que mostra um coração. As capas dos artistas "Alex Harvey" e "Tin Spirits" também funcionam de maneira positiva, ao mostrarem ícones da cultura pop, tais como um samurai e a caveira mexicana, respectivamente.

No caso dos artistas "Kendrick Lamar" e "Ketzer", por sua vez, os estímulos nas capas não resultaram em atitudes favoráveis por parte dos entrevistados. Apesar de trazer a cor verde, que é uma cor favorita de indivíduos masculinos (Carvalho,2015), ela não passou emoções positivas para os entrevistados na capa do disco de Lamar. Já a capa de "Ketzer" trouxe sensações de "indignação", "terror", "tristeza", mostrando que os entrevistados tiveram atitudes menos positivas ou, até, negativas quanto à mulher encapuzada. Somente um entrevistado teve uma atitude mais positiva sobre a capa, dizendo que demonstrava "coragem" do artista, porque era "altamente discutível" como capa para um disco do seu trabalho.

\subsubsection{Heurística sobre capas de discos}

A heurística está presente nos relatos de alguns entrevistados quando falam sobre a compra de alguns discos a partir de suas capas. Alguns entrevistados tiveram a intenção de compra imediata somente visualizando a arte da capa. Porém, quando souberam o estilo de música que o artista possui, houve o pensamento de desistência da compra.

Os diferentes tipos de heurística sugeridos por Peter e Olson (2009) são identificados nos relatos. A "heurística de busca" é percebida nos relatos dos 
entrevistados sobre as capas dos artistas "Kendrick Lamar", "Bethel Music", "Premiata Forneria Marconi" e "Focus". Segundo os entrevistados, tais capas permitem uma visualização simples, mostrando informações relevantes sobre a sonoridade do artista à primeira vista, relatando que o som tocado pelo artista é o que reflete na capa. Por exemplo, a capa do disco de "Bethel Music", que apresenta um coração, faz referência ao estilo musical gospel que a banda toca, conhecido por ser uma música da alma, que vem de dentro, ou seja, que viria do coração. Os outros três artistas, "Kendrick Lamar", "Premiata Forneria Marconi" e "Focus", possuem discos cujas capas são "simples" ou "bastante complexas", por apresentarem, por exemplo, "a cor esverdeada" ou "desenhos mirabolantes", de forma que os entrevistados acreditem que a música reflita tal simplicidade ou complexidade dos artistas.

A "heurística de avaliação" avalia e pondera as crenças com base no objetivo que será enfocado no processo de resolução de um problema. Esse tipo de heurística é visto nos relatos dos entrevistados que falam sobre a capa do artista "Mac Miller", pois mostra uma situação inusitada, em que a crença pessoal atua livremente na hora da ponderação sobre a escolha em comprar. No caso da capa do artista "Mac Miller", alguns entrevistados disseram que sentiam sono ou achavam que o homem estava rindo de alguma coisa.

Já em relação à "heurística de escolha", que é um procedimento simples de comparação entre alternativas, com o objetivo de escolher uma delas, tal heurística encontra-se presente nos relatos dos entrevistados que falaram sobre as capas das bandas "Aurora" e "Hardy Kuster". Dizem isso por acreditar que a imagem da cantora ou da borboleta nas capas dos discos se relacionam com a evolução natural da música eletrônica.

\subsubsection{Intenção de Compra dos Discos a partir das Capas}

A partir da análise das capas dos discos, os entrevistados indicaram quais comprariam sem que soubessem mais informações sobre a banda ou seu estilo musical. O Quadro 4 apresenta a indicação de cada entrevistado sobre o disco que compraria. Vale atentar que existem duas capas alternativas, que foram usadas quando o entrevistado conhecia a banda da capa original. 
Quadro 4 - Intenção de compra de álbum por entrevistado

\begin{tabular}{|c|c|c|c|c|c|c|c|c|c|c|}
\hline Entrevistado & Capa 1 & Capa 2 & Capa 3 & Capa 4 & Capa 4 alternativa & Capa 5 & Capa 5 alternativa & Capa 6 & Capa 7 & Capa 8 \\
\hline 1 & 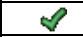 & & 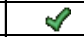 & 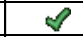 & & & & 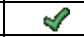 & & \\
\hline 2 & & $\theta$ & $q$ & & & & & & $\mathscr{Q}$ & 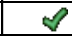 \\
\hline 3 & & & 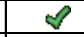 & & & 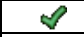 & & 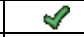 & & \\
\hline 4 & $\mathscr{Q}$ & & 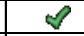 & & $\mathscr{Q}$ & & $\mathscr{Q}$ & & & $\theta$ \\
\hline 5 & & & & & & & 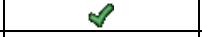 & 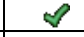 & & \\
\hline 6 & & 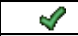 & $\emptyset$ & $\emptyset$ & & & & & & 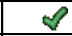 \\
\hline 7 & & & & & 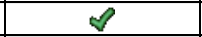 & & & & & $q$ \\
\hline 8 & & & 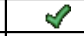 & & & & & $\mathscr{Q}$ & & \\
\hline 9 & & 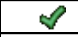 & & & & 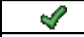 & & $\emptyset$ & & $\theta$ \\
\hline 10 & & 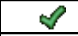 & & $\mathscr{Q}$ & & & & & $\mathscr{Q}$ & 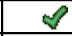 \\
\hline 11 & & & & & & & & 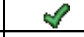 & & \\
\hline 12 & & & & & 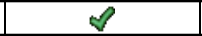 & & & & & 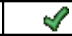 \\
\hline 13 & & & & & 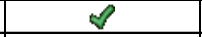 & & $\emptyset$ & & & \\
\hline 14 & & & & & & 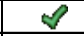 & & $\mathscr{A}$ & & 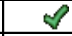 \\
\hline 15 & & & & & 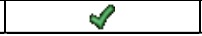 & & $\mathscr{Q}$ & & & \\
\hline
\end{tabular}




\section{Conclusão}

O presente estudo teve como objetivo identificar e analisar os fatores que levam consumidores a comprarem discos por impulso, somente avaliando suas capas. Para isso, foram realizadas 15 entrevistas em profundidade com consumidores que já compraram discos por impulso, no passado. A partir da análise dos dados, é possível chegar a algumas conclusões.

A pesquisa indicou que percepção, atitude e heurística são elementos do comportamento do consumidor que estão presentes no ato de comprar um disco por impulso somente analisando sua capa. Dependendo das imagens contidas nas capas, existe um (ou alguns) componente(s) mais acentuado(s) do que outros, que são impactantes, e que, por vezes, são mais importantes do que outros fatores (tais como preço) para determinar a compra do disco. Porém, é de difícil compreensão qual fator é mais importante que o outro somente analisando os apelos que precisam ser colocados em capas de discos para que seus reais significados sejam entendidos pelos consumidores.

Entretanto, usar uma abordagem de marketing para um assunto relacionado a arte é complexo, pois discos e suas capas são expressões de um artista, e nem sempre ele quer que seu disco ou capa sejam facilmente entendidos. Capas de álbuns são importantes porque podem durar tanto quanto a música em si. As capas são uma embalagem permanente e repousam na prateleira ou na estante por anos, sendo vistas e revistas frequentemente, especialmente quando a música é tocada. Este hábito cria um vínculo permanente entre o consumidor e o autor da obra e a capa do álbum é um importante elemento para essa ligação, pois tangibiliza, de certa forma, as intenções ou sentimentos do artista ou banda com as músicas.

A psicologia do consumidor revela os fatores inconscientes presentes no simples ato de uma compra. No caso de discos, a personalidade do autor ou banda encontra-se retratada em sua capa, levando os consumidores a valorizarem, não só os fatores de percepção, atitude e heurística, mas também a identificarem-se com o autor, sua música e suas ideias. Nesse sentido, a capa do disco ou álbum pode ser, na compra por impulso, o principal fator que irá estabelecer uma relação entre o consumidor e o artista. Assim, em termos de 
marketing, é fundamental reconhecer que para o mercado fonográfico, mesmo com a concorrência da internet, capas de discos e álbuns são e continuam sendo elementos chave na criação da ponte entre consumidor e produto a ser consumido.

Dessa forma, mesmo na era da internet, o fator psicológico envolvido na compra de discos ou álbuns mantém-se importante. Mesmo com toda tecnologia atual e um comportamento consumidor cada vez mais individualizado, a necessidade de estabelecer relações de admiração e identificação com autores e suas obras permanece. As entrevistas comprovam como os consumidores relacionam-se e apaixonam-se por autores e obras e como essas relações são duradouras e importantes para a construção da personalidade das pessoas.

A interpretação da capa do álbum depende muito de cada indivíduo, pois cada um tem uma opinião e visão diferente sobre a imagem, e sobre o que aquilo significa. Às vezes, a capa que contém muitos elementos gráficos como a capa do "Focus", por exemplo, pode significar muita coisa para o fã do que para um leigo que não conheça a música da banda.

\subsection{Implicações Gerenciais}

As capas tiveram avaliações positivas e negativas. A capa mais vista como positiva pelos entrevistados foi a do artista "Hardy Kuster". Juntar a borboleta/mariposa junto com uma mão humana trouxe uma beleza para a capa, que não lembra em nada o estilo musical apresentado pelo artista. Apesar de ter uma avaliação negativa dos entrevistados, a capa do artista "Ketzer" foi a segunda mais votada na intenção de compra dos álbuns listados. Vale-se notar que, apesar de ser uma capa considerada "pesada", houve uma curiosidade dos entrevistados para tentar entender o porquê do artista colocar essa capa no seu trabalho.

Pode-se observar que as duas capas são extremos. Uma simbolizando a "paz", e a outra simbolizando o "terror". Muitos artistas optam por mostrar artes mirabolantes, copiar quadros famosos, tentam revolucionar fazendo artes estranhas. Mas atentando que existem duas artes simples, mão humana e borboleta de um lado, e uma mulher "nua" encapuzada de outro, mesmo simples podem causar um burburinho e o interesse de compra mais fácil do que uma arte inovadora. Capas com algum símbolo ou significado simples são mais compreendidas e aceitas pelo público do que capas estranhas que, às vezes, não possuem significado algum relacionado ao álbum. 
As capas vistas com menos agrado pelos entrevistados foram as capas dos artistas "Kendrick Lamar", "Premiata Forneria Marconi" e "Mac Miller". Para a capa do "Kendrick Lamar", muitos dos entrevistados disseram que somente a cor verde não é suficiente para o ímpeto da compra. É necessário talvez outro estímulo para que o consumidor possa entender melhor o que o artista está comunicando em sua música, mesmo que a capa seja algo simples demais e seja o interesse do artista em ser assim. Isso vale para a capa do artista "Mac Miller", pois uma capa em que há um homem bocejando deixa o consumidor bem longe do produto. Os entrevistados relataram sono e desleixo ao ver essa capa, e o artista não teve essa intenção ao lançar essa capa. Apesar da capa do "Premiata Forneria Marconi" ser clássica no gênero de música do artista e mostrar o que o artista é dentro da música, algo místico e bonito, como reflete na capa, não houve uma intenção clara dos consumidores para comprar o disco.

\subsection{Sugestões e recomendações para futuros estudos}

Como desdobramentos futuros, essa linha de estudo pode ser desenvolvida através de uma investigação mais a fundo sobre o mesmo referencial teórico, porém abordando outras linhas teóricas como, por exemplo, a psicologia em seus aspectos individuais e coletivos.

Ainda, entende-se que é possível explorar e aprofundar as questões estudadas neste trabalho através de pesquisas que busquem compreender melhor fatores cognitivos, emocionais e relacionais que podem influenciar a escolha dos indivíduos na compra por impulso de um disco ou álbum devido a uma determinada capa ou mesmo um atributo da capa. 


\section{Anexos}

\section{Anexo 1 - Roteiro da Entrevista e Capas analisadas}

Bom dia/boa tarde/boa noite. Eu sou aluno da PUC e o objetivo dessa entrevista é uma conversa sobre capas de álbuns. Não pense que existem respostas certas ou erradas às perguntas que vou fazer, o importante é o que você pensa.

Em nenhum momento da pesquisa você será identificado. Eu não vou citar o seu nome na pesquisa; somente vou identificar sua entrevista por um número. Então, fique a vontade para falar o que quiser. As informações que você relatar hoje serão usadas somente para fins acadêmicos.

Para facilitar o trabalho, nossa conversa será gravada. Assim, não será necessário tomar notas e podemos conversar com maior tranquilidade. Garantimos que essa gravação vai ser utilizada somente para a análise do que conversamos aqui, hoje, e nada mais. Tudo bem?

Se você precisar fazer alguma pergunta durante a entrevista, pode interromper a conversa a qualquer momento.

\section{Parte 1) Perguntas sobre experiências pessoais com álbuns}

Você já comprou algum álbum somente olhando para a sua capa? (Pergunta filtro)

(Caso sim à resposta anterior, seguir com as perguntas)

1. Conte como foi/foram essa(s) compra(s). Onde foi que você comprou esse álbum? Havia alguma circunstância especial para você comprar o álbum?

2. O que mais chamou a sua atenção para a capa do álbum?

3. Por que você acha que a capa te encantou?

4. O que você pensou sobre a música da banda/artista quando olhou para a capa?

5. Você continua comprando álbuns só olhando para a capa, mesmo com o advento da Internet? Exemplifique melhor essa relação atualmente... 
6. A capa é um elemento importante que dá vontade de conhecer uma banda nova?

\section{Parte 2) Perguntas sobre capas de álbuns}

Nessa etapa, teremos 8 capas ao total, (de 2 bandas conhecidas e 6 de bandas desconhecidas):

1) Você já viu essa capa de álbum? (Pergunta filtro)

2) O que mais chama a sua atenção ao olhar para essa capa?

3) O que você pensa a respeito da música da banda/artista quando olha para essa capa?

4) Qual estilo musical que você acha que a música desse álbum pertence quando olha para essa capa? Evidencie e explique o porquê.

5) (Após mostrar todas as capas ao entrevistado): Quais das capas mostradas você mais estaria propenso a comprar? 
As capas a seguir:

\section{Capa 1)}

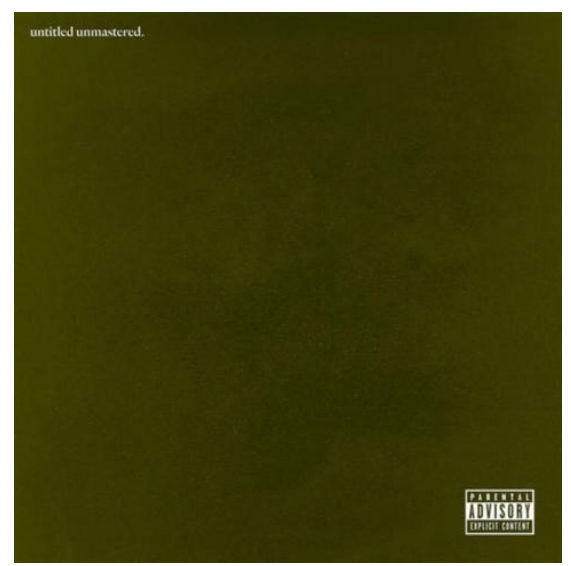

Artista: Kendrick Lamar

Album: untitled unmastered.

Lançado: 2016

Estilo: Hip Hop

\section{Capa 2)}

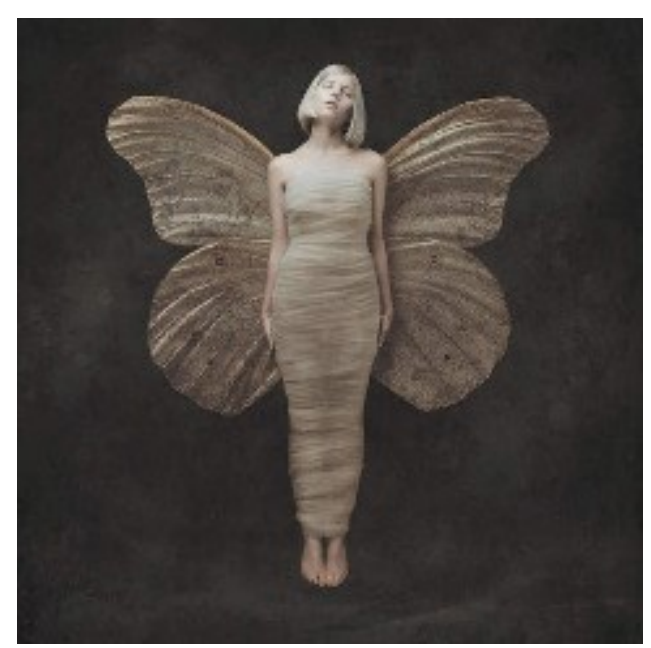

Artista: Aurora

Album: All My Demons Greeting Me As A Friend

Lançado: 2016

Estilo: Synthpop 
Capa 3)

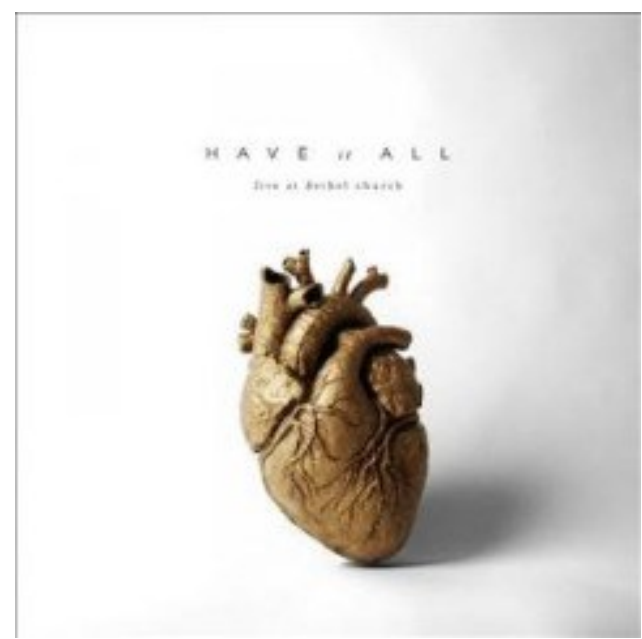

Artista: Bethel Music

Album: Have It All Live

Lançado: 2016

Estilo: Música Gospel

\section{Capa 4)}

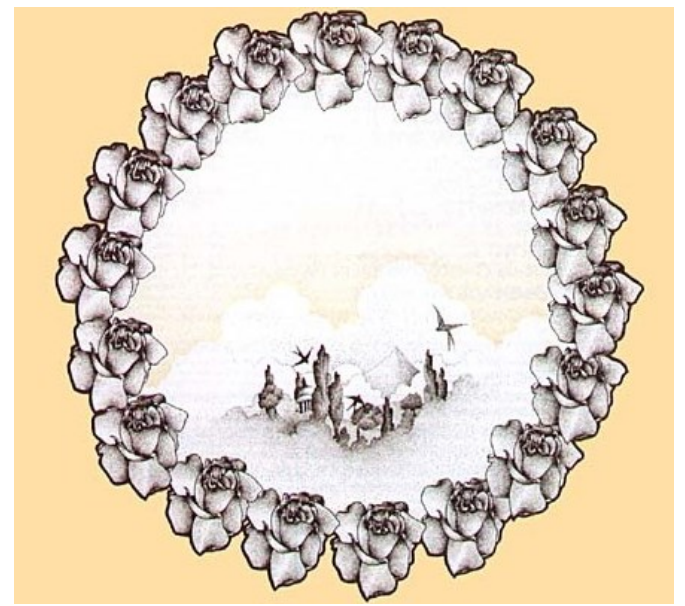

Artista: Premiata Forneria Marconi

Album: Photo of Ghosts

Lançado: 1973

Estilo: Rock progressivo 
Capa 4 alternativa)

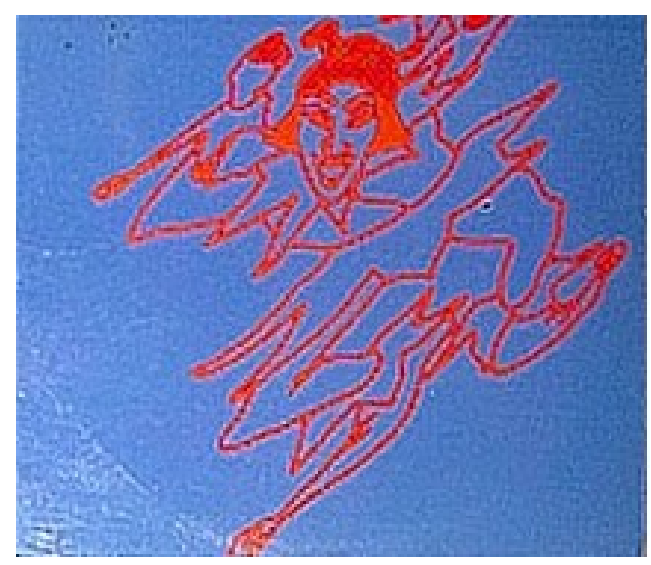

Artista: Alex Harvey

Album: Joker is Wild

Lançado: 1972

Estilo: Rock

\section{Capa 5)}

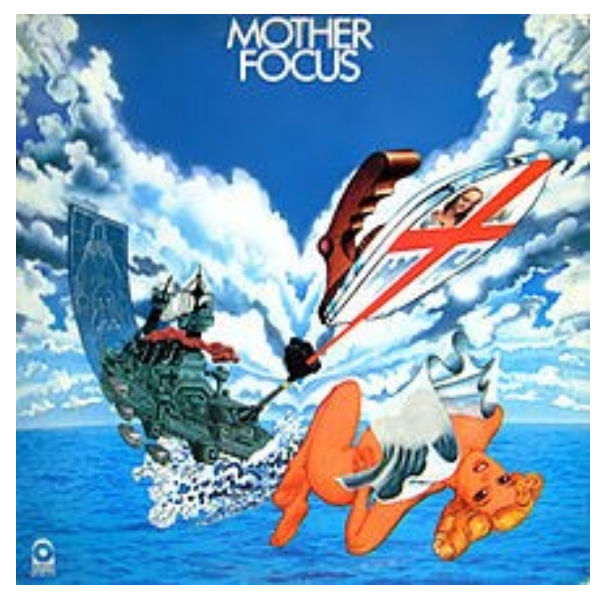

Artista: Focus

Album: Mother Focus

Lançado: 1975

Estilo: Funk, Jazz Pop, Rock Instrumental e Rock progressivo 


\section{Capa 5 alternativa)}

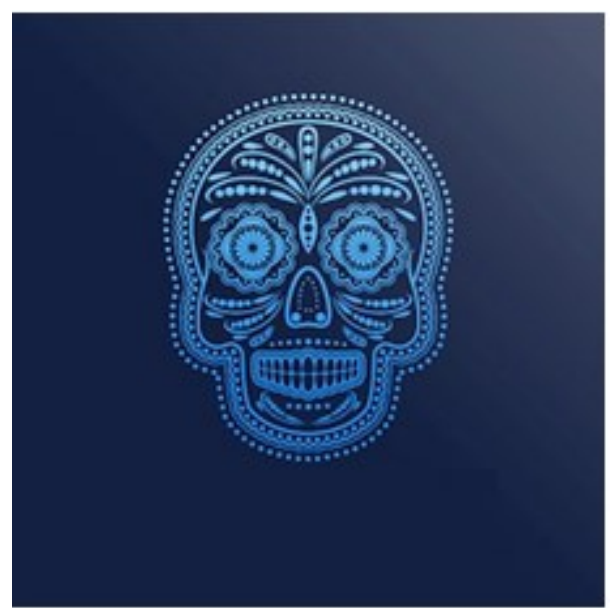

Artista: Tin Spirits (ex-guitarrista do XTC)

Album: Wired to Earth

Lançado: 2012

Estilo: Rock

\section{Capa 6)}

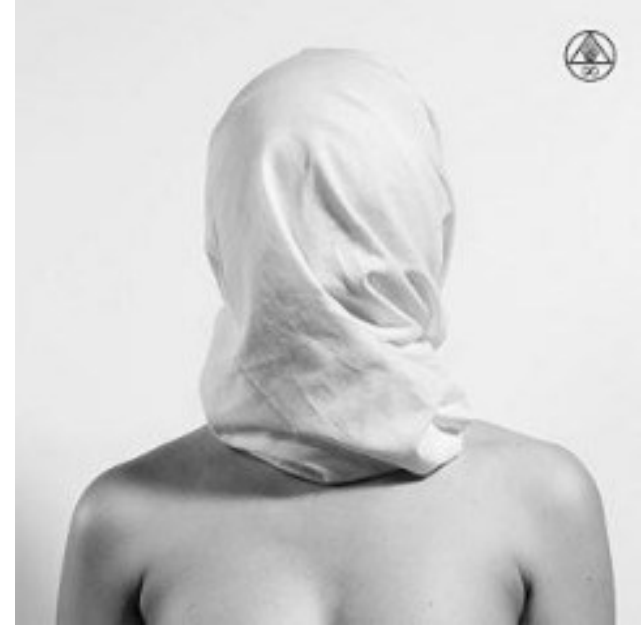

Artista: Ketzer

Album: Starless

Lançado: 2016

Estilo: Metal 
Capa 7)

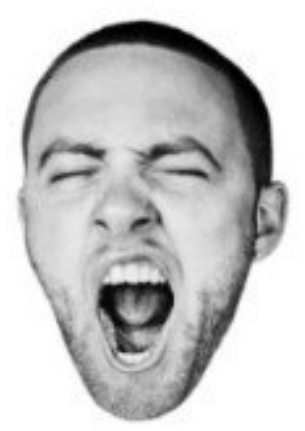

MIIIIIIIII

Artista: Mac Miller

Album: Good AM

Lançado: 2016

Estilo: Hip Hop

\section{Capa 8)}

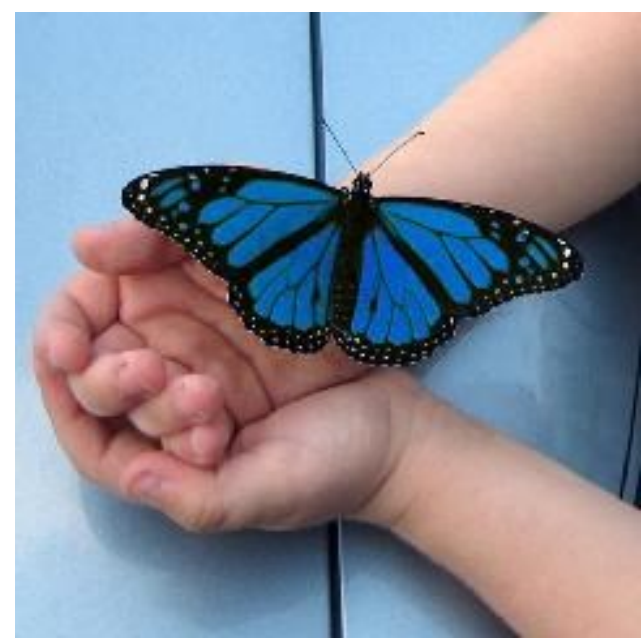

Artista: Hardy Kuster

Album: Mariposa Azul

Lançado: Música Eletrônica

Estilo: 2016 
Por fim, gostaria de pedir algumas informações sobre você:

Qual é a sua data de nascimento?

Qual é a sua profissão?

Qual é o seu grau de escolaridade?

Obrigado pela participação 


\section{Referências Bibliográficas}

AAKER, David A.; KUMAR, V.; DAY, George S. Pesquisa de marketing. São Paulo: Atlas, 2001.

ADMINISTRADORES; Renda gerada com venda de vinis ultrapassa serviços como Spotify e YouTube Disponível em http://www.administradores.com.br/noticias/entretenimento/renda-gerada-comvenda-de-vinis-ultrapassa-servicos-como-spotify-e-youtube/105921/ Acesso em: 10 março.2016

CALHEIROS, Edna; ABMI - Mercado Fonográfico Mundial e Brasileiro em 2014. Disponível em http://www.abmi.com.br/website/arquivos/legislacao/mercado-fonogra-ficobrasileiro-e-mundial-2015-abr2015-versaofinal.pdf Acesso em: 13 set.2015

CARVALHO, Henrique. Viver de Blog Psicologia das Cores. Disponível em: http://viverdeblog.com/psicologia-das-cores/ Acesso em: 20 set.2015

CRUZ, Felipe Branco. Música UOL. Disponível em: http://musica.uol.com.br/noticias/redacao/2015/07/30/microsoft-me-disse-que-omp3-nao-iria-durar-diz-criador-do-formato-htm/ Acesso em 24 out.2015

ENGEL, James F.; BLACKWELL, Roger D.; MINIARD, Paul W. Comportamento do Consumidor. 8.ed. Rio de Janeiro: LTC Ed., 2000.

EVANGELISTA, Ronaldo. Os operários da música livre. Revista Galileu. Ed Globo, v.2601, p.44-53, mar.2013.

EVANGELISTA, Ronaldo. Revista Galileu. Disponível em: http://revistagalileu.globo.com/Revista/Common/0,,EMI331605-17773,00OS+OPERARIOS+DA+MUSICA+LIVRE.html Acesso em 20 set.2015

FERRAZ, Ana. Carta Capital. Disponível em: http://www.cartacapital.com.br/revista/899/entre-dois-mundos Acesso em 06 maio.2016 
GERHARDT, Tatiana Engel; SILVEIRA, Denise Tolfo. Métodos de Pesquisa. Disponível em: http://www.ufrgs.br/cursopgdr/downloadsSerie/derad005.pdf Acesso em 10 abril.2016

GIL, Antonio Carlos. Como elaborar projetos de pesquisa. $4^{a}$ ed. São Paulo. Atlas,2002.

HASTIE, Reid e DAWES, Robyn M. Rational Choice in na Uncertain World. The Psychology of Judgment and Decision Making. USA: Sage Publications, 2001.

HOYER, Wayne D; MACINNIS, Deborah J.; Comporamento do Consumidor. $5^{\mathrm{a}}$ Ed. São Paulo. Cengage Learning. 2001

IFPI - Global Music Report 2016 http://www.ifpi.org/downloads/GMR2016.pdf Acesso em 12 maio.2016

LIMA, Tamires Vianna de; SPERS, Eduardo Eugênio. Marcas, Heurísticas e Vieses na Tomada de Decisão do Produtor Rural. VI Congresso de Administração da ESPM. São Paulo, 2009. Disponível em: http://caepmblog.espm.br/EVENTOS/IVSimposio/Artigos/Marcas, \%20heuriticas\% 20e\%20vieses\%20na\%20tomada\%20\%20de\%20decisao.pdf Acesso em 27 out.2015

MATTAR, Fauze Najib. Pesquisa de marketing: volume 1 : metodologia, planejamento. 6. ed. rev., atual. e ampl. São Paulo: Atlas, 2005.

MALHOTRA, Naresh K.; ROCHA, Ismael. Introdução à pesquisa de marketing. $1^{\text {a }}$ ed. São Paulo: Pearson/Prentice Hall, 2005.

PETER, J. Paul; OLSON, Jerry C. Comportamento do consumidor e estratégia de marketing. $8^{\mathrm{a}}$ ed. São Paulo: McGraw-Hill, 2009.

PETER, J. Paul; OLSON, Jerry C. Consumer Behavior \& Marketing Strategy. McGraw-Hill/Irwin series in Marketing. $7^{\text {a }}$ ed. 2005. 
SANTANA, Ana Flávia Ribeiro; PÉREZ-NEBRA, Amália R.; Será que imagem é mesmo tudo? Descrição de variáveis que impactam a retenção da propaganda na memória. Comunicação \& Inovação. São Caetano do Sul, v.9, n.17(p13-24). 2008 Disponível em :

http://seer.uscs.edu.br/index.php/revista comunicacao inovacao/article/viewFile/ 704/551 Acesso em 02 nov.2015

SCHIFFMAN, Leon G; KANUK, Leslie Lazar. Comportamento do Consumidor. $6^{\mathrm{a}}$ ed. Rio de Janeiro: LTC, 2000.

SOLOMON, RR. Comportamento do Consumidor: Comprando, Possuindo e Sendo. $9^{\mathrm{a}}$ ed. Editora Bookman, S.A. Porto Alegre, 2011.

TADEU, Regis. Há 30 anos, "Powerslave" derretou os nossos cérebros. Disponível em: https://br.noticias.yahoo.com/blogs/mira-regis/ha-30-anospowerslave-derreteu-os-nossos-cerebros-194134938.html Acesso em 03 set.2015 